\title{
O gdańskiej poezji rodzinnej XVIII wieku
}

Edmund Kotarski 


\section{EDMUND KOTARSKI}

\section{O gdańskiej poezji rodzinnej XVIII wieku}

N

a wiek XVII przypada w Gdańsku wcześniej niespotykany rozwój poezji okolicznościowej. Jej dzieje wyznaczają wydarzenia związane przede wszystkim z panowaniem kolejnych władców polskich, elekcje i uroczystości koronacyjne, wjazdy królów do miasta nad Motławą, zwycięskie kampanie wojenne, zakończone pomyślnie pertraktacje pokojowe, dni żałoby po zgonie monarchy. Wiele okazji do uprawy poezji tego typu dostarczyło życie mieszkańców Gdańska. Autorzy - znani i nieznani, anonimowi - sięgali po pióro, by uczcić burgrabiów, burmistrzów, rajców i ławników, komendantów miasta i ich podwładnych, profesorów Gimnazjum Gdańskiego i duchownych. Pisano z okazji ich imienin i rocznicy diei natalis, pisano, by uczcić wyniesienie ich na urząd, pamiętano, gdy zawierali związek małżeński, gdy ich potomkowie przychodzili na świat, gdy trzeba było utworem żałobnym pożegnać tych, którzy swoją pracą i zasługą kształtowali gdańską codzienność, tworzyli władzę municypalną, gdański system szkolny, decydowali o religijnym i wyznaniowym obliczu miasta.

W XVII wieku odnotować można również pierwsze próby poezji rodzinnej, inaczej mówiąc: powstają wówczas w Gdańsku wiersze pisane przez członków rodziny. Wymienić tu można utwory imieninowe, których autorzy - członkowie rodzin i przyjaciele - składali w nich dowody pamięci, wyrażali uczucia miłości, wdzięczności i przywiązania. Gerard Rogge - przykładowo - w wierszu imieninowym dedykowanym matce dziękował jej za opiekę i serce. Zawarł w nim też pragnienie (wyrażone w pierwszej osobie liczby pojedynczej):

Dass ich durch mein gantzes Leben

Mich wil kindlich untergeben

Ihrer trewen Mutter-Hand...'

Uczucia miłości i przywiązania zamanifestował również Gabriel Schumann, zwracając się do ojca chrzestnego i stryja. Cenił je - podkreślił - tym wyżej, że świat opanowany został przez przemoc, tyranię, nędzę. W stwierdzeniu tym nawiązał

1 W. Gerson, G. Rogge, Auff der Viel-Ehr und Tugend-Reichen Frawen Susanna Roggin, gebohme von Puttin [...] am 24. May des jetztlauffenden 1660 Jahres einffalenden Nahmens-Tag Wohl-meinend gerichteter Glück-Heil und Lebens Wundsch, [Gdańsk 1660]. Egz. Biblioteki Gdańskiej Polskiej Akademii Nauk (dalej: BG PAN), sygn. Oe $202^{\circ}$ adl. 118. 
do skutków wojny trzydziestoletniej (pisał w 1649 roku), do ciężkich doświadczeń wielu krajów. Na koniec zauważył:

Doch last uns näher gehn, zu unsern lieben Polen...2

I ten kraj przeżywał - zauważył autor - trudne chwile. Właśnie dlatego szczególnie wysoko cenić należy uczucia miłości i przyjaźni.

W gronie rodzinnym powstawały też epitalamia. W dniu 30 czerwca 1648 roku odbył się ślub Mikołaja Bodecka i Konstancji Giese, córki rajcy gdańskiego. Brat panny młodej, Konstanty, wystąpił wówczas z dwoma wierszami weselnymi ${ }^{3}$ : łacińskim, adresowanym do pana młodego, i niemieckim - do panny młodej. Wprowadził do nich - stosownie do okoliczności - postacie Apollina, Bachusa i Junony (pominął natomiast Wenerę i Kupidyna), symbolizujących słońce, wiosnę, odradzającą się naturę, radość, piękno i szczęście małżeńskie. Autor przywołał w swych epitalamiach także motywy róży, tulipana, rozmarynu i światła jako symbole życia, wiosny, szczęścia i miłości.

Przykładów z wieku XVII można by podać więcej, lecz prawdziwy rozkwit poezji domowej, rodzinnej stał się udziałem dopiero następnego stulecia.

Rodzina w Gdańsku w tym czasie tworzyła wspólnotę obejmującą w zasadzie rodziców i dzieci, jakkolwiek zdarzały się wspólnoty nadal wielopokoleniowe, liczące - łącznie ze służbą - od ośmiu do dziesięciu osób ${ }^{4}$. Jeśli nawet nie żyły one pod jednym dachem, to jednak zawsze obejmowały krewnych, zarówno ze strony ojca jak i matki. Wychodzono więc poza ramy jednej generacji; poczucie więzi rodzinnej rozciągano na wiele pokoleń, a nawet linii pokrewieństwa. Krewni żyli na ogół w rozproszeniu, nawet w różnych stronach Europy, lecz utrzymywali ze sobą kontakt, choć spotykali się nieczęsto; bywało, że osobiście w ogóle się nie znali. Do tego kręgu zaliczano również przyjaciół domu, rezydentów - formalnie do rodziny nie należących, zawsze jednak do niej zaliczanych. To ważna konstatacja, gdy mówimy o gdańskiej poezji rodzinnej.

Wracając do literatury, zauważmy, że wśród szeroko rozumianej rodziny powstawały wówczas takie formy poetyckiej wypowiedzi, jak genetliakon, epitalamium, epitafium i epicedium. Należały one od dawna do repertuaru form poezji okolicznościowej, lecz o ile przez lata całe służyły przede wszystkim uświetnieniu narodzin królewskiego potomka, potomków burmistrza i rajcy, uroczystości ślub-

${ }^{2}$ G. Schumann, Dem Edlen [...] Herrn Gabriel Schumann, [...] Rathsverwandten der Königlichen Rechten Stadt Dantzig, [...] eines Theils Herrn Paten, beydertheils Herrn Vettern am 18. Martius des 1649 Jahres bey damals glüklich einfallendem Nahmenstage aus schuldiger Ehrerbietung Überreichete Bind und Glückwündsche..., [Gdańsk 1649]. Egz. BG PAN, sygn. Oe $202^{\circ}$ adl. 56.

${ }^{3} \mathrm{~K}$. Giese, Auff Hochzeitliches Ehren-Fest des Edlen und Wolweisen Hn. Nicolaus von Bodeck, Rahtsverwandten der Republic hieselbst, und der [...] Jungfraw Constantia Giesen [...], [Gdańsk 1648]. Egz. BG PAN, sygn. Oe $30.8^{\circ}$ adl. 144a.

‘ M. Bogucka, Lebensformen der Danziger Einwohner während der frühen Neuzeit (16-18 Jh). W: Zwei Hanseatische Städte Bremen und Danzig im Laufe der Jahrhunderte. Materialien des wissenschaftlichen Kolloquiums vom 10/11. Dezember 1993 an der Universität Gdańsk (Danzig), Gdańsk 1994 , s. 67. 
nych i pogrzebów osób znanych w Rzeczypospolitej, a w każdym razie w mieście, o tyle w XVIII wieku, a zwłaszcza w drugiej połowie tego stulecia stanowiły istotny element uroczystości rodzinnej, co wcześniej - w stuleciu na przykład XVII - obserwowało się rzadziej. Narodziny potomka, ślub i zgon traktowano w XVIII wieku coraz częściej przede wszystkim jako wydarzenie rodzinne, rodowe, a nie publiczne.

W roli twórców wierszy występowali członkowie rodziny - podkreślmy to raz jeszcze - w szerokim tego słowa rozumieniu. Pisząc utwory na urodziny, śluby i pogrzeby stawali się oni kimś w rodzaju bardów rodzinnych5. Podział kompetencji był tu dość wyraźny. Epitalamia na przykład pisali bracia wychodzących za mąż sióstr. Oni też patronowali samej uroczystości zaślubin i weselnej. Natomiast wiersze urodzinowe najczęściej nie wychodziły spod pióra najbliższych członków rodziny, oczywiście na wyjątki zawsze można się powołać. $Z$ kolei utwory pisane z okazji diei natalis, a więc w rocznicę urodzin na przykład ojca czy matki były dziełem dzieci, przede wszystkim synów.

Mówimy o autorstwie rodzinnym, musimy jednak pamiętać, że członkowie rodzin w wielu wypadkach wyręczali się osobami spoza swojego kręgu. Prawdopodobnie bardzo często pióra swego udzielali nauczyciele, zwłaszcza domowi, i sekretarze, choć ani swego imienia, ani nazwiska nie ujawniali. Podpisywali się członkowie rodziny - stosownie do okoliczności. Dziś trudno rozstrzygnąć w sposób nie budzący wątpliwości, w jakim wypadku można mówić o autorstwie „rodzinnym”, w jakim zaś w grę wchodzi mistyfikacja. Jakkolwiek było, jedno wszakże nie ulega wątpliwości: uroczystości rodzinne, obrzędowość związana z narodzinami, ze ślubem i weselem, z pogrzebem wreszcie pobudzały życie literackie tamtego czasu. Naturalnie, w skali skromnej, w granicach zamkniętego środowiska, w obrębie rodziny - jako niebagatelny element scenariusza uroczystości rodzinnej, chociaż ukryć się nie da, że twórczość ta, jeśli nie w całości, to zapewne w części, docierała także do szerszej publiczności.

Zauważmy w tym miejscu, że w poezji, o której mówimy, posługiwano się najczęściej - żeby nie powiedzieć: wyłącznie - językiem niemieckim. Łacina wprawdzie jeszcze od czasu do czasu językowi temu towarzyszyła, lecz już sporadycznie.

Pozostała językiem oficjalnym, urzędowym, nie stała się jednak językiem uroczystości rodzinnej i związanych z nią wierszy okolicznościowych. W końcu nie wszyscy członkowie rodziny znajomość łaciny posiedli. Dotyczyło to w szczególności kobiet. Joanna Schopenhauer, matka filozofa, pochodząca z zamożnego domu kupieckiego, uczyła się francuskiego, tłumaczyła teksty z tego języka na język niemiecki i odwrotnie, uczyła się nadto kaligrafii, trochę geografii ${ }^{6}$. Wyniosła nadto nawyk czytania, także czasopism. O łacinie jednak nie było mowy. Jej matka, Elżbieta z domu Lehmann - o pokolenie starsza - posiadła jeszcze skromniejszy

${ }^{5}$ L. Ślękowa, Muza domowa. Okolicznościowa poezja rodzinna czasów renesansu i baroku. Wroclaw 1991, s. 14.

${ }^{5} \mathrm{~J}$. Schopenhauer, Gdańskie wspomnienia młodości. Tłum. i objaśnił T. Kruszyński. Wrocław 1959, s. 92. 
zasób wiedzy i umiejętności. „Kilka polonezów - wspominała Joanna Schopenhauer - kilka mazurków na fortepianie, kilka pieśni, do których sama umiała sobie akompaniować, umiejętność czytania i pisania na domowy użytek - to było prawie wszystko, czego ją nauczono" "W tych warunkach językiem poezji rodzinnej łacina stać się nie mogła. Zastąpiły ją języki nowożytne, niemiecki przede wszystkim.

Przejdźmy do następnych kwestii. Bohaterem utworu - w wypadku poezji rodzinnej nie mogło być inaczej - stawał się członek rodziny, a nie dostojnik państwa czy miasta. W wierszach eksponowano nie przynależność do szerszej społeczności, nie udział w życiu publicznym, w państwie czy choćby w mieście, lecz więź rodzinną, rolę w rodzinie. Prawidłowość tę obserwujemy w genetliakonach i wierszach powstałych $w$ rocznicę diei natalis, $w$ wierszach weselnych i żałobnych.

Wiersze uświetniające narodziny potomka znała starożytność. Występowały one wówczas pod różnymi nazwami: genethliacon, genethliacum ${ }^{8}$, natalitium, carmen natalitium ${ }^{9}$. Uprawiali je między innymi Wergiliusz i Stacjusz, lecz ani w ich czasach, ani później nie upowszechniły się one w takim stopniu, jak utwory pisane na rocznicę diei natalis. Fakt ten pozostawał z pewnością w ścisłym związku z wysoką śmiertelnością wśród dzieci, w tym także, a nawet przede wszystkim, wśród noworodków ${ }^{10}$. Nie inaczej było w osiemnastowiecznym Gdańsku. I tutaj również należały genetliakony do rzadkości, jakkolwiek i wiersze na rocznicę urodzin nie zdarzały się często, jeśli zachowane teksty upoważniają nas do dywagacji liczbowych.

Genetliakon ani w Grecji, ani w Rzymie nie funkcjonował jako gatunek literacki. Tę świadomość miał również Scaliger, czemu dał wyraz w swym traktacie Poetices libri septem ${ }^{11}$. Autorzy nie stworzyli wyróżniających się w sposób szczególny schematów kompozycyjnych, nie powołali do życia topiki, którą można by odtąd uznać za charakterystyczną dla poezji urodzinowej. Maciej Kazimierz Sarbiewski w swoich wykładach zauważył jedynie, że genetliakon jest utworem opiewającym "nowo narodzone dziecię już to ze względu na nadzieje z nim związane, już to $z$ uwagi na jego przodków"12. Dopowiedzmy: motyw urodzin lub (zdecydowanie częściej) rocznicy urodzin wprowadzali autorzy - od starożytności poczynając do różnych struktur gatunkowych ${ }^{13}$. Mogła to być elegia (przykładów dostarczają

\footnotetext{
${ }^{7}$ Ibidem, s. 11.

${ }^{8}$ Tu posługujemy się zapisem spolszczonym: genetliakon.

${ }^{9}$ Por. T. Michałowska, Staropolska teoria genologiczna. Wroctaw 1974, s. 173-174.

${ }^{10}$ Nie można tu wszelako zapominać o zmianach następujących w ciągu XVIII stulecia. Pisze o nich P. Chaunu (Cywilizacja wieku Oświecenia, tłum. E. Bąkowska, Warszawa 1989, s. 119): „Kurczy się, a potem zanika śmierć cykliczna. Jakie sa tego następstwa praktyczne? Zanik śmierci cyklicznej przeobraża podświadomość zbiorową, zmienia piramidę wieku ludzkiego. Cykliczne nawroty epidemii były śmiercią selektywną. Skracała życie starców, dodatkowo okrzesywała trochę całą piramidę wieku ludzkiego, czyniąc spustoszenia zwłaszcza wśród noworodków i dzieci. Wyrównanie w ciągu stulecia krzywej umieralności to przede wszystkim zasadnicze zmniejszenie śmiertelności wśród dzieci - dodatkowa szansa dla powołanych do życia, a tym samym zachęta, aby poświęcić czas na staranniejsze ich wykształcenie, które z kolei stwarza szansę dodatkowych lat egzystencji”.

11 J. C. Scaliger, Poetices libri septem, 1561, s. 155-156.

${ }_{12}$ M. K. Sarbiewski, O poezji doskonałej czyli Wergiliusz i Homer. Tłum. M. Plezia, oprac. S. Skimina. Wrocław 1954, s. 493 (246).

${ }^{13}$ H. Szelest, „Sylwy” Stacjusza. Wrocław 1971, s. 59.
} 
Tibullus, Owidiusz, Propercjusz), w grę wchodzić mogły ponadto epigramy (można się tu powołać na Marcjalisa), listy (dość zajrzeć do Auzoniusza), pieśni (przykłady u Stacjusza), a nawet satyry (o czym świadczy twórczość Persjusza) ${ }^{14}$. Niezależnie od wspomnianych tu form poetyckich znano w starożytności również mowę urodzinową, której teorię opracowali Dionizjusz z Halikarnasu i Menander. Według nich mowa tego typu - podobnie jak inne oracje laudacyjne - powinna się składać ze wstępu, pochwały dnia urodzin, pory roku, na którą ten dzień przypadał, miejsca urodzenia, ojczyzny, rodziny. Dalszym bardzo ważnym komponentem powinna być pochwała bohatera mowy, uwzględniająca właściwości fizyczne, przymioty charakteru, wykształcenie, zawód. W wypadku dziecka, o którym niewiele można było powiedzieć, należało pamiętać o przepowiedni przyszłości ${ }^{15}$. Stałym elementem, zarówno poetyckich jak i prozaicznych tekstów urodzinowych, były życzenia kierowane do nowo narodzonego dziecka lub solenizanta, zakończone w wielu wypadkach modlitwą. Do często powracających komponentów zaliczyć wypada także element gnomiczny, wnoszący do poezji urodzinowej rozważania o ogólnym charakterze ${ }^{16}$.

Takie doświadczenia pisarskie mieli lub mogli mieć w polu swego widzenia gdańscy twórcy poezji urodzinowej. Wywodzili się oni z kręgu rodzinnego. Nie oznacza to jednak, że w poezji tej, o czym już wspomniano, wypowiadali się zawsze najbliżsi, wyłącznie najbliżsi, na przykład ojcowie czy bracia. Wśród autorów pojawiał się bodaj częściej „oddany domowi sługa”, „najgłębiej oddany sługa”, „zobowiązany sługa”, „posłuszny sługa”. Czuł się on widocznie członkiem rodziny, człowiekiem blisko związanym z domem, $w$ którym właśnie z radością witano potomka, skoro fakt ten postanowił uczcić okolicznościowym wierszem.

Natomiast utwory powstałe $w$ rocznice urodzin podpisywali najbliżsi, najczęściej synowie, choć spotkać można się także z formułą szerszą: dzieci. Do wyjątków zaliczyć można przyjaciółkę czy przyjaciela figurujących w tytule wierszy, do czego jeszcze wrócimy.

Niektóre utwory nawiązywały do oratorskiej odmiany poezji urodzinowej, i to oczywiście - w jej wersji pochwalnej. Jako przykład podać można wiersz Jana Wilhelma Güntera ${ }^{17}$. Jego adresatem był ojciec nowo narodzonego dziecka, raczej: on przede wszystkim. On też obdarzony został największymi pochwałami, jego syn zaś przedstawiony został jako dziedzic ojcowskich cnót:

\section{Dein Geist, Dein muntrer Geist, ist Ihm schon beygelegt}

\footnotetext{
${ }^{14} \mathrm{lbidem}$, s. $59-60$.

${ }^{15}$ Ibidem, s. 60.

${ }^{16}$ Ibidem, s. 63.

${ }_{17} \mathrm{~J}$. W. Günther, Die frohe Geburt eines Hofnungsvollen Sohnes, welcher dem [...] Herrn Johann Heinrich Soermann, E. Wohledlen und Wohlweisen Gerichts der Alten-Stadt würdigen Mitgliede und angesehenen Handlungsmanne hieselbst, von Seiner vortreflichen Gemahlin den 15 Merz 1763 zur ungemeinen Freude dieses hohen Hauses und der ganzen vornehmen Familie geschenket wurde, entwarf in diesen Zeilen ein ergebenster Diener..., Danzig [1763]. Egz. BG PAN, sygn. Oe $552^{\circ}$ adl. 66 .
} 
a także matczynych:

Und auch der Mutter Bild mit in sein Herz geprägt...

Wiersz swój poprzedził autor mottem o charakterze gnomicznym zaczerpniętym z Horacego, z jego ody (IV, 4, 29-32) wychwalającej cnoty rodu julijsko-klaudyjskiego, które objawiły się - według poety - w młodych Neronach:

Fortes creantur fortibus et bonis;

Est in iuvencis, est in equis patrum

Virtus nec inbellem feroces

Progenerant aquilae columbam.

To istotne uzupełnienie tekstu głównego, jeśli zważyć, że w przytoczonej zwrotce wyraził Horacy myśl, iż dzielni i zacni rodzą dzielnych, iż orlik nie spłodzi gołąbki.

Potomek - to kolejny motyw wiersza - rozjaśnia wszystkie dni, kładzie kres wszelkim smutkom... Stwierdzeniom tym towarzyszą metafory światła, jasności. Monolog kończą życzenia skierowane do rodziców:

Der Ewge laße Euch an Glück, an Wohlfarth blühn, Und Eurer Söhne Schmuck, der Welt zum Nutz erziehn.

Uderza w genetliakonie Günthera powściągliwość w wyrażaniu radości. Wynikała ona zapewne $z$ doświadczenia, jakie było udziałem współczesnych. Wysoka śmiertelność wśród niemowląt ${ }^{18}$ (i w ogóle dzieci) dyktowała ostrożność w manifestowaniu uczuć, liczenie się ze słowem, z wyrażaniem zbyt radosnych emocji. Uderza jeszcze jedno zjawisko: usytuowanie dziecka na drugim planie. $W$ wierszu zaznaczono przede wszystkim obecność rodziców, domowników, skupiono się na ich przeżyciach, ich odczuciach. Również życzenia zostały do nich skierowane, właściwie wyłącznie do nich.

\footnotetext{
${ }^{18}$ Występowała ona także wśród matek. Literackim śladem tego, że narodziny dziecka pociągały za sobą śmierć matki, niech będzie wiersz, w którego tytule jest powiadomienie i o narodzinach syna, 1 o zgonie matki. Utwór sam jest już tylko epicedium: D.J.M., Der in Freude und Leyd bemerkte Unbestand, bey Gelegenheit dessen als der Höchste Herrn Johann Wilhelm Näthler und Frau Constantia Elisabeth geb. Gräbern den 6ten November Anno 1758 durch Dero ersten Sohn mildiglich enfreuet; als welcher den 9ten eiusd. unter Benamung Wilhelm Eduard durch priesterliche Handlung und den Bund der heiligen Taufe zur Kirchen St. Petri und Pauli der Gemeine Gottes einverleibet worden, in einfolgen Gedanken entworfen, und zur Zeit da es dem weisen Rahtschluß Gottes hinwiederum gefällig gewesen diese theure Ehegenossin Herrn Johann Wilhelm Näthler und einzige geliebteste Frau Tochter Herrn Jacob Gräber, den 5ten Tag nach Ihrer Entbindung aur dieser Zeit in die selige Ewigkeit zu versetzen und deren entseelten Leichnam den 16ten desselben Monats unter Begleitung von einem nach Standes Unterscheid geschehenen ansehnlichen Leichengefolge nach St. Elisabethskirche begleitet worden, auch nachhero zur Oberpfarrkirchen St. Marien in Seinem Ruhekämmerlein beygesetzet, Beyden Geehrtesten Häusern als Denkmahl tiefester Verpflichtung übergeben von..., Danzig [1758]. Egz. BG PAN, sygn. Oe $552^{\circ}$ adl. 51.
} 
Wiersz Günthera nie należy pod tym względem do wyjątków. Nowo narodzone dziecko $z$ reguły nie stawało się bohaterem utworu, przeciwnie: $w$ tym charakterze - z woli autora - występował ojciec. Znamienny z tego punktu widzenia jest wiersz Abrahama Groddecka (podpisującego się: d[er] G[ottes] G[elahrtheit] B[eflissener] ${ }^{19}$. Autor, nie ukrywający imienia i nazwiska, a przedstawiający się jako Gehorsamst verbundener Diener, był z pewnością spokrewniony z ojcem (może był jego bratem, może bratankiem?) urodzonego właśnie synka, to znaczy z Beniaminem Groddeckiem (1720-1776), profesorem greki i języków orientalnych w Gdańskim Gimnazjum Akademickim. Swojemu wierszowi urodzinowemu nadał tytuł Moralisches Gedicht, wypełnił go zaś rozważaniami nad źródłami ludzkiego zadowolenia, szczęścia, na koniec pochwałą przyjaźni i miłości:

\section{O welch ein Pinsel mahlt ihr reizendes Gesicht}

Und welch ein ander Gut hält ihr das Gleichgewicht.

Żadna inna wartość, żadne inne dobro nie może równać się z miłością. Końcowym składnikiem tej refleksji jest stwierdzenie, że synek Groddecka jest owocem miłości. Postać dziecka została przywołana tylko w tym kontekście. Wbrew tradycjom poezji urodzinowej autor nie usytuował synka profesora w przeszłości rodziny, ani też nie roztoczył przed nim wizji przyszłości. W miejsce klasycznego genetliakonu wkroczył wiersz refleksyjny czy refleksyjno-dydaktyczny, komponent gnomiczny wziął górę nad elementem panegirycznym.

Była to praktyka częsta, lecz nie jedyna. Na cześć noworodka pisano też ody. Autorem jednej z nich był Bernard Alm ${ }^{20}$. Zaczął ją od pełnych patosu zwrotek:

\section{O holde Regung! sanfte Liebe! \\ Du wirkst die angenehmste Triebe \\ Und wohl noch nie empfundne Lust; \\ Du führest mit dir Süßigkeiten, \\ Verschaffest Lust, und Seltenheiten \\ Bewegen jede zarte Brust.}

Wenn wir berauscht von dir geführet, Und du das zarte Herz gerühret,

Das Herz das standhaft glaubt zu seyn,

${ }_{19}$ Abraham Groddeck, d[er] G[ottes] G[elahrtheit] B[eflissener], Als der [...] Herr M. Benjamin Groddeck, öffentlicher Lehrer der Griech. und Oriental. Sprachen am hiesigen Gymnasio durch die glückliche Entbindung Seiner Wehrtgeschätzten Ehe-Genossen den 5ten des Hornungs 1758 mit einem jungen Sohn erfreuet wurde widmete nachstehende Zeilen zum Zeichen seiner Hochachtung, Liebe und Ergebenheit ein diesem Hochzuverehrenden Hause gehorsamst verbundener Diener..., Danzig [1758]. Egz. BG PAN, sygn. Od $173882^{\circ}$ adl. 42.

${ }_{20} \mathrm{~B}$. Alm, Bey der Geburth des jungen Herrn Benzmanns überreichte gegenwärtige Ode ein diesem Hohen Hause verbundener Diener [...] Im Jahr 1756 im Hornung, Danzig [1756]. Egz. BG PAN, sygn. Oe $642^{\circ}$ adl. 14. 
Da lehrest du uns erst erkennen,

Dich angenehm und schön zu nennen,

Warum? was wir gewünscht trift ein.

Du schenkst dem Greise neue Kräfte,

Und seine fast verloh'ne Säfte

Erquickest du zu seiner Lust.

Er fühlt bey sich ein holdes Regen

Und ein $\mathrm{Ihm}$ angenehm Bewegen,

Bemächtiget sich seiner Brust.

Adresatem tych słów - należących do kręgu topiki pochwalnej - jest nowo narodzony synek. W kolejnych zwrotkach oda przechodzi w narrację, w opowieść 0 miłości rodziców. Natomiast pod koniec górę bierze wypowiedź skierowana do nich, ukazująca ich szczęście, spełnienie ich pragnień i oczekiwań. Utwór - jak zwykle w genetliakonach - zamykają życzenia:

Euch aber schön verbundne Herzen, Muß nie ein Unglücksfall verletzen,

Kein Kummer, Schmerz, doch da Euch schon

Der Himmel selbst scheint zu beglücken,

So wird er es gewiß auch schicken,

Daß Euch bald küßt, der zweyte Sohn.

I w tym wypadku, i w innych wierszach urodzinowych adresatami życzeń są z reguły rodzice, zwłaszcza $w$ tych genetliakonach, które wyszły spod pióra przyjaciół domu, którzy podpisywali się jako unterthänigst verpflichtester Diener, tiefverbundenster Diener czy unterthäniger Diener. Można się tu powołać na genetliakony powstałe $w$ roku 1756 z okazji narodzin synka burgrabiego królewskiego Gotthilfa Wernicka (1720-1773) ${ }^{21}$. Autorzy tych wierszy w dziecku widzieli przede

${ }^{21}$ Als der [...] Herr Gotthilf Wernick, höchstverdienter Königl. Burggraf durch die Entbindung Seiner vortrefflichen Gemahlin mit einem jungen Sohne im Jahr 1756 den 7, Decembr. höchstens erfreuet wurde suchte seine Hochachtung und Pflicht zu bezeigen ein diesem hohen Hause unterthänigst verpflichtester Diener, Danzig [1756]. Egz. BG PAN, sygn. Oe $642^{\circ}$ adl. 43. Od $298^{\circ}$ adl. 1; Die hohe Geburt eines Hoffnungsvollen Sohnes welcher dem [...] Herrn Gotthilf Wernick, Königlichem Burggraf wie auch Rahtsverwandten der Rechten-Stadt Danzig von Seiner vortrefflichen Gemahlin den 7. December 1756 zur allgemeinen Freude Danzigs geschenket wurde besang ein tiefverbundster Diener, Danzig [1756]. Egz. BG PAN, sygn. Od $298^{\circ}$ adl. 1; Oe $642^{\circ}$ adl. 44; J.A.L., Als der [...] Herr Gotthilf Wernick, höchstverdienter Königl. Burggraf durch die Entbindung Seiner vortrefflichen Gemahlin mit einem jungen Sohne erfreuet wurde wolte seine Unterthänigkeit an den Tag legen ein unterthäniger Diener [...] Im Jahr 1756 den 7. December, Danzig [1756]. Egz. BG PAN, sygn. Od $298^{\circ}$ adl. 2; Oe $642^{\circ}$ adl. 45; Als der [...] Herr Gotthilf Wernick, höchstverdienter Königl. Burggraf, durch die Entbindung Seiner vortrefflichen Gemahlin mit einem jungen Sohne im Jahr 1756 den 7. Decembr. höchstens erfreuet wurde suchte seine Hochachtung und Pflicht zu bezeigen ein diesem hohen Hause unterhänigst verpflichtester Diener, Danzig [1756]. Egz. BG PAN, sygn. Od 29 $8^{\circ}$ adl.3. 
wszystkim dziedzica nazwiska, tradycji rodzinnej, cnót przodków, dóbr przez nich zgromadzonych. Narodziny dziecka potraktowali nadto jako spełnienie oczekiwań i pragnień rodziców, jako źródło ich radości. Jeden z nich ${ }^{22}$ - anonim zauważył, że spojrzenie dziecka napawa rodziców radością, pozwala zapomnieć o wszelkich lękach i cierpieniach. Spoglądał na dziecko z perspektywy rodziców, ich przeżyć, doznań i uczuć. Pamiętał o nim jeszcze w życzeniach, do których włączył motyw Opatrzności Bożej:

Des Himmels Schutz umarme Dich, Dein Wachsthum blüh und mehre sich, Die Vorsicht leite Deine Jugend:

Dich zier ein Geist mit klugem Witz, Sey Deines Hauses Glanz und Stütz, Und folge dermaleinst des grossen Vaters Tugend.

Ein immerdaurend Wohlergehn, Laß Vorsicht dieses Haus umstehn, Behüt es selbst mit wachen Händen:

Schick Ihm noch mehr Vergnügen zu, Beschirme Dessen Lust und Ruh, Laß Deiner Gottheit Strahl Ihm stetes Heyl zuwenden.

Przywołany tu anonimowy twórca nie był - w stylu kształtowania swego utworu - odosobniony. Przeciwnie, utrzymywał się w granicach konwencji, której podporządkowywali się również inni autorzy przy okazji narodzin potomka Wernicka. Niewiele miejsca wyznaczyli realiom związanym z dzieckiem. Dominantą uczynili perspektywę rodzicielską. W gruncie rzeczy bowiem bohaterami genetliakonu podkreślmy to raz jeszcze - stawali się rodzice, zwłaszcza ojcowie. Autorzy nie zapominali nawet 0 ich pozycji w mieście. Wernicka na przykład przedstawiali zawsze jako burgrabiego, a jego potomka jako burgrabiowskiego syna (Burggrafs-Sohn). Posługujący się literonimem J.A.L. ${ }^{23}$ w jednej ze zwrotek swego genetliakonu zdobył się na taką oto refleksję:

Beglückt ist solch Geschlecht, das die Vermehrung sieht! Sein Stamm, sein Ruhm, sein Nahm, kennt keiner Zeiten Ende, Und wenn ein Vater gleich zu seinen Vätern flieht, So ist sein Sohn, den er in seiner Stelle pfände.

W następnej zwrotce od tego uogólnienia przeszedł autor do osoby Wernicka i dodał:

${ }^{22}$ Por. przyp. 20 - chodzi o pienwszy z wymienionych tam wierszy.

${ }^{23}$ Por. przyp. 20 
Wenn grosser Männer Stamm, die Stadt, sich mehren sieht; Beglückt ist sie! Das Glück kommt selbst ihr in die Hände: Denn, wenn gleich mancher Greis hier zur Verwesung zieht, So bleiben dennoch nie, ohn Männer, Aemter, Stände.

W wypowiedziach tego typu, w których przedstawiano dziecko jako dziedzica nazwiska, tradycji rodzinnej, autorzy chętnie posługiwali się słownictwem poetyckim wywodzącym się ze świata roślinności. Życzenia nowo narodzonemu składali w takich na przykład słowach:

So lebe zarter Zweig! ja, grüne, wachse, blüh...

W skrajnym wypadku genetliakon stać się mógł wręcz erotykiem. Dokazał tego bliżej nam nie znany J.G. Basky, który - co wówczas nieczęsto się zdarzało - w tytule swego wiersza na pierwszym miejscu wymienił matkę nowo narodzonej córeczki, i to z imienia i nazwiska, ojca zaś potraktował drugoplanowo, nie podając nawet jego imienia ${ }^{24}$. Wystąpił $w$ tym swoistym erotyku $z$ pochwałą miłości jako siły towarzyszącej ludzkości od jej początków, jako szczególnego daru, który może stać się udziałem człowieka:

Nicht des Golds gehäufter Schimmer, Nicht der Freundschaft Zärtlichkeit, Selbst die Ehre schenkt uns nimmer, So gerechte Fröhlichkeit, Solche Ruhe in dem Herzen, Solchen Frieden in der Brust, Solchen Schutz vor allen Schmerzen, Als der Liebe edle Lust.

Wiersz kończą życzenia - tradycyjnie już skierowane do rodziców. A dziecko? Jest darem ich miłości. Tyle o nim.

Czas przejść do wierszy pisanych na dzień urodzin. Powstały one w kręgu ściśle rodzinnym. To zapewne sprawiło, że tak niewiele tekstów do naszych dni się zachowało. Nie ulega wszakże wątpliwości, iż powstawały one w ciągu całego XVIII stulecia. Pochodzący z samego początku wieku, bo 1702 roku, wiersz był autorstwa dwóch synów - Jana Augusta, studenta teologii, i Jana Ferdynanda, którzy napisali go na cześć ojca, Jana Marcina Königa, komisarza królewskiego

\footnotetext{
${ }^{24}$ J.G. Basky, Als die [...] Frau Dorothea Florentina Flandern bey Ihrer höchst enfreulichen Geburt mit einer jungen Tochter erfrauet wurde wollte Dero Hochgeehrten Ehegemahl als auch Dero Hochgeehrten Mama und Allesammt Denen, die an dieser Freude Theil nehmen mit diesem Gedicht seine Schuldigkeit am Tage legen ein tief verbundenster [...]. Anno 1757 den 10 May. Danzig [1757]. Egz. BG PAN, sygn. Oe $642^{\circ}$ adl. 72.
} 
emporium w Gdańsku i Elblaggu ${ }^{25}$. Z końca wieku pochodzi wiersz ${ }^{26}$ pióra W. Weickhmanna ${ }^{27}$, napisany w rocznice urodzin ojca. W tym samym - 1796 - roku opublikowane zostały dwa inne wiersze urodzinowe: jeden na dies natalis matki podpisany przez wyjątkowo liczną gromadę dzieci, syna, córki, zięcia, synową i wnuka, Karola ${ }^{28}$, drugi dedykowany przyjacielowi przez przyjaciółkę, zapewne jednocześnie autorkę ${ }^{29}$. Nieco wcześniej powstał wiersz ofiarowany siostrze Juliannie Dorocie Schwartz przez dwóch braci ${ }^{30}$. Wymieńmy jeszcze dwa inne wiersze z końca wieku. Stylizacja ich tytułów wprawdzie nie upoważnia do włączenia tych utworów do poezji ściśle rodzinnej, pozwala jednak przyjąć, że między ich nadawcami i adresatami zachodziła więź bliskiej serdecznej przyjaźni ${ }^{31}$. Wynika to zresztą nie tylko z tytułów, lecz także z zawartości myślowej i emocjonalnej utworów. Można tu z całą pewnością mówić o zbieżnościach między tymi wierszami a twórczością rodzinną.

Co łączy te utwory? Niewątpliwie kilka powtarzających się motywów: element gnomiczny, uświetnienie rocznicy, oddanie hołdu solenizantowi i życzenia. W strukturze carminis natalium ku czci matki ${ }^{32}$, obchodzącej 54 urodziny, najważniejsze miejsce zajmuje wizja senna, w której zarysowany został obraz uroczystości urodzinowej - z wyliczeniem jej uczestników, z sielankową przestrzenią, pośród której wygłasza się pochwałę solenizantki. Wiersz zamykają: pochwała dnia urodzin (Heil nun dem Tage...), a nawet godziny (Heil der Stunde...) i prośba skierowana do Boga:

\section{Laß, Vater, sie uns noch zum Trost und Seegen!}

po której następują słowa nadziei:

und er, der gerne hilft, erhört auch uns.

${ }_{25}$ Johannes Augustus König, S.S. Theol. Studios, Johannes Ferdinandus König, Hertzlicher Wunsch, womit den [...] Herrn Johann Martin Königen, Vornehmen Königl. Commisario des Portorii zu Dantzig und Elbingen, als ihren vielgeliebten Herrn Vater bey dessen höchst-erwünschten herannahrnden Geburths-Tage, den 19. Novembr. st. $n$. des itztlauffenden 1702 Jahres ihre schuldige Pflicht und Gehorsam hertzinniglich abstatten wollen desselben jederzeit gehorsamste Söhne..., Dantzig [1702]. Egz. BG PAN, sygn. Oe $342^{\circ}$ adl. 149.

${ }_{26} \mathrm{~W}$. Weickhmann, Epistel am Geburtstage meinen verehrungswürdigen Vaters gesungen von [...]. Den 19. August 1796, Danzig [1796]. Egz. BG PAN, sygn. Oe $738^{\circ}$ adl. 9.

${ }^{27}$ Imienia Weickhmanna nie udało się ustalić. Poprzestać trzeba na skrócie: W.

${ }_{28}$ Zur festlichen Wiederkehr des 14ten Februars 1796 der verehrungswürdigsten Mutter geweiht von Ihren liebenden Kindern..., Danzig [1796]. Egz. BG PAN, sygn. Oe $738^{\circ}$ adl. 7.

${ }^{29}$ Dem Geburtsfeste eines würdigen Patrioten und verehrten Freundes von einer Freundin. Danzig, den 12. May 1796, [Danzig 1796]. Egz. BG PAN, sygn. Oe $738^{\circ}$ adl. 8.

${ }^{30}$ D. F. C. und J. F. C., An Frau Juliana Dorothea Schwartz bey Ihrem Geburts-Feste von [...]. Danzig den 14 Februar 1790, [Danzig 1790]. Egz. BG PAN, sygn. Oe $778^{\circ}$ adi. 1.

${ }^{31}$ Carl Fayerabend, Epistel. Meinem lieben Freunde Reinhold Rawicz an Seinem Vier und Zwanzigjärigen Geburtstage übergeben von [...]. Danzig, den 19ten Merz 1791, [Danzig 1791]. Egz BG PAN, sygn. Oe $738^{\circ}$ adl. 3; E.G.S., Bey der feyerlichen Erinnerung an die beyde erste Lebenstage des Herrn Krieges-Rath Weiß und Dessen verehrungswürdigen Frau Gemalin den 15. und 17 May 1792 von..., Danzig [1792]. Egz. BG PAN, sygn. Oe $778^{\circ}$ adl. 15.

${ }^{32}$ Znamy jedynie jej nazwisko: Schneider 
Wiersz darowany przez synów ojcu, Janowi Marcinowi Königowi, złożony z sześciu sestyn (ababcc), w aż czterech z nich przynosi refleksje na temat kruchości ludzkiej egzystencji. Człowiek - w przeciwieństwie do kosmosu - przemija. Natura nieustannie się odradza, orzeł potrafi sam przywrócić swą młodość, feniks dźwiga się z popiołów - człowiek tych możliwości nie posiada. Po tych ogólnie ujętych rozważaniach następuje - zwyczajem wierszy na dies natalis - pochwała dnia urodzin jako dnia radości, słońca, pogodnego nieba, wezwanie do zabawy:
Nun Himmel schwängert euch mit Seegen und Gedeyn, Und schliest diß theure Haupt in frische Rosen ein! Schaft daß die Lüfte Gold, die Wolcken Perlen schneyen, Die Speisen Ambrosien, die Träncke Nectar seyn, Und wenn euch Willman wird umb euren Willen fragen, So last ihm allemahl, man will, zurücke sagen.

W. Weickhmann swój wiersz zatytułował: Epistel am Geburtstage, a zaczął go od przytoczenia słów, które miał wypowiedzieć Aleksander Wielki wobec swego nauczyciela - Arystotelesa:

\section{Die Menschheit gab mein Vater mir,} Die Menschlichkeit verdank ich Dir.

Po tak rozpoczętym liście na dzień urodzin następują wyrazy wdzięczności za czuwanie nad wychowaniem, za troskliwość, czułość, łagodność, za wszystkie nauki. Jest to wypowiedź bardzo osobista, żeby nie powiedzieć: intymna, której towarzyszy też świadomość niewypłacalności:

Wie kann ich Deine Güte Dir vergelten;
jedoch zu dem, der über tausend Welten,
mit unbegränzte Allmacht thront
steigt mein Gebet, daß er es Dir belohnt
und aus dem Füllhorn seiner Güte
der reinsten Freuden Rosenblüte
auf Deine Lebenspfade streut,
daß jeder Tag Dein Glück erment;
daß jene unschäzbare Freuden
der Ehe und der Kinderliebe,
der Freundschaft und Geselligkeit
der Tod noch lange, lange Zeit
nicht stören möge...

Nietrudno zauważyć, że wartości, które w przytoczonych słowach zostały przywołane, pozostawały w ścisłym związku z życiem rodzinnym, ze szczęściem małżeńskim, z miłością dzieci i przyjaźnią. Ani śladu oficjalności, nic o roli ojca poza 
rodziną. List pozostał do końca wypowiedzią osobistą, słowem syna skierowanym do ojca.

Inaczej pomyślany został wiersz przyjaciółki do przyjaciela. Już tytuł - Dem Gebeurtsfeste eines würdigen Patrioten und verehrten Freundes - wprowadza nas w jego odrębną myślowo i emocjonalnie zawartość. Powtarzają się wprawdzie znane $z$ innych wierszy urodzinowych schematy kompozycyjne, lecz całość pozbawiona jest tego osobistego, intymnego tonu, który przepajał wspomniane już utwory. Początek przynosi refleksje o przemijaniu człowieka i nieustannym odradzaniu się natury:

Doch kehrt auch wieder, was verschwunden schien,

Der schöne May mit seinem Blumenkörbchen,

Der Sommer mit der segensreichen Garbe,

Und mit dem Füllhorn reifer Frucht - der Herbst...

Ludziom, solenizantowi pozostaje tylko wzdychać do przeszłości, do wiosny własnego życia:

Wir sehen nur im Bilde fremder Jugend,

Was einst auch wir in unserm Frühling waren.

Po tej części następuje pochwała przyjaźni i patriotyzmu - wartości w tym wierszu najwyżej cenionych. Utwór zamykają - zgodnie z regułami obowiązującymi w poezji urodzinowej-życzenia, utrzymane w tonacji wyriźnie patetycznej:
Ja, sey beglükt, wie einst die Patrioten
Des àlten Roms, die nach des Staates Dienst
Den schönen Abend ihrer großen Tage
Im stillen Schatten ihrer Bäume lebten.

Wiersze urodzinowe realizowały założenia poezji osobistej, odwołującej się do określonych norm intymności. Uprawiane przez członków rodziny lub powstałe $z$ ich inspiracji, uwzględniały jednostkowe wydarzenia i związane $z$ tym przeżycia. Piszący prezentowali typ przeżywania zindywidualizowanego, typ emocji subiektywnych. Monolog przez nich kształtowany był wypowiedzią prywatną, osobistą, nawet wyznaniem. Górowała w nim indywidualna, osobista wizja zdarzenia; przewagę zdobywał osobisty punkt widzenia w jego ocenie. Relacja między podmiotem mówiącym a adresatem, zawsze określonym, z reguły skonkretyzowanym, opierała się na intelektualnym i uczuciowym porozumieniu między obiema stronami, układała się na zasadzie osobowej więzi. Znajdowało to wyraz w kształtowaniu monologu według reguł wypowiedzi zwróconej bezpośrednio do adresata jak już wspomnieliśmy - wyraźnie wskazanego. W tym układzie było też miejsce na refleksje ogólniejsze. Skupiały się one wokół życia, człowieka, wartości.

Poezja urodzinowa głosiła pochwałę więzi rodzinnej i przyjaźni, podnosiła rangę rodziców i dzieci w tworzeniu tych wartości, budowała autorytety w najbliższym 
otoczeniu, chętnie powracała do roli miłości jako siły kształtującej ciepło rodzinne. Eksponowała znaczenie tradycji rodzinnej, lecz milczała na temat wspaniałości rodu, zasług przodków, także przyszłości dziecka - skupiona przede wszystkim na chwili, na radościach i nadziejach, jakie niosły z sobą dzień narodzin i rocznica urodzin.

Przejdźmy do epitalamiów. Stanowiły one ważną cząstkę gdańskiej poezji rodzinnej. Zacząć wypada od autorów. Byli wśród nich oczywiście członkowie rodziny, $z$ reguły bracia pana młodego lub panny młodej: pflichtschuldigster Bruder, liebender Bruder. Przykładowo pochodzące z roku 1701 epitalamium zostało napisane przez Karola Beniamina Gottwaldta, brata panny młodej ${ }^{33}$, córki nieżyjącego już wówczas gdańskiego lekarza i przyrodnika Krzysztofa Gottwaldta, która zawierała związek małżeński z Gabrielem Groddeckiem, profesorem filozofii w Gimnazjum Gdańskim. Podobne przykłady spotykamy w późniejszych latach, również pod koniec wieku, dokładnie: $w 1791$ roku $^{34}$. Z kolei autorem powstałego w roku 1749 wiersza weselnego był brat pana młodego, Karol Wilhelm Soermann ${ }^{35}$. $W$ tej roli występowali także rodzice, niekiedy rodzeństwo (nie tylko bracia) lub szerzej - krewni, spowinowaceni. Jeden przykład z 1761 roku $^{36}$, drugi z $1791^{37}$. Zupełnie wyjątkowe miejsce zajmuje epitalamium, które młoda para, Karol Gabriel Schmidt i Dorota Luiza Schnaase, dedykowała swoim gościom ${ }^{38}$.

Odnotujmy w tym miejscu, że autorzy bardzo często nie podawali ani swoich imion, ani nazwisk, pozostawali anonimowi. Czy jednak do końca? Raczej nie, skoro posługiwali się literonimami ${ }^{39}$, a więc pseudonimami składającymi się z liter, będących niekiedy - przyjąć można - inicjałami imion i nazwisk osób dobrze znanych adresatom wierszy. Towarzyszyły im w niektórych wypadkach graficzne

${ }^{33}$ Carl Benjamin Gottwaldt, Die in Myrten verwandelte Cypressen, welche in einem wolmeinenden Gedichte an dem Hochzeitlichen Ehren-Tage beyderseits Verlobten der [...] Jungfrauen Euphrosina Elisabeth, des Weyland [...] Herrn Christoph Gottwaldts, M.D. und Hochverordneten Practici und Physici ordinarii dieser Stadt Hertzgeliebten nachgelassenen Jungfr. Tochter und des [...] Herrn $M$. Gabriel Groddecks, Philospohiae Proffesoris und Bibliothecarii, wie auch zu Leipzig des Collegi B. Mariae Virginis Collegiati, da selbiger den 11. Januarii dieses 1701 Jahres mit gewöhnlichen Solennitäten celebriret worden, aus Schuldigkeit und Gehorsam ausführen wollen beyderseits vereinigten Beliebten Ergebenster Bruder und Diener..., Dantzig [1701]. Egz. BG PAN, sygn. Oe $342^{\circ}$ adl. 105.

${ }^{34}$ W. D. S[chweer], Der Vermählungsfeyer des Bünsowschen und Schweerschen Brautpaars geweihet von einem zärtlich liebenden Bruder [...] Den 17ten Februar 1791, Danzig [17911. Egz. BG PAN, sygn. Oe $40068^{\circ}$

${ }^{35}$ Carl Wilhelm Soermann, Die vortheilhafte Wirkung einer vernünftigen Eigenliebe betrachtete bey dem Soermann-und Braynischen Eheverbündnisse, welches den 22ten May 1749 vergnügt vollzogen wurde, und bezeugte zugleich dem verbundenen Paare seine Ergebenheit und Bayfreude, Desselben pflichtschuldigster Bruder..., Danzig [1749]. Egz. BG PAN, sygn. Ms 1095 IV 31.

${ }_{35}$ J. P. G., Isaac und Rebecca eine Schäfererzehlung, Der Weischnur und de la Portischen zu Danzig volzogenen Eheverbindung gewidmet von einem Anverwandten... Im Jahr 1761 den 21. April, [Danzig 1761]. Egz. BG PAN, sygn. Oe $552^{\circ}$ adl. 78.

${ }^{37}$ Am Vermählungstage unsers lieben Onkels Daniel Gottlieb Bünsow mit Jungfer Anna Sabina Schweers in tiefer Achtung gewidmet von Seinen Neffen und Nichten sämtlichem Geschwister Bünsow. Danzig, den 17ten Februar 1791, [Danzig 1791]. Egz. BG PAN, sygn. Oe $40078^{\circ}$ adl 1.

${ }^{38}$ C. G. Schmidt, D. L. Schnaase, Die Hochzeitsfeyer, ein Traum. Ihren Gästen gewidmet von, Danzig, den 13. Sept. 1796, [Danzig 1796]. Egz. BG PAN, sygn. Oe $818^{\circ}$ adl. 43.

${ }^{39}$ D. Świerczyńska, Polski pseudonim literacki. Warszawa 1983, s. 113-118. 
oznaczenia autorstwa, tzw. grafonimy ${ }^{40}$, łączące litery na przykład z gwiazdkami: $\mid \mathrm{S}^{\star \star} \mathrm{H}^{\star \star 41}$. Wreszcie spotkać można kognationimy, tzn. pseudonimy określające pokrewieństwo ${ }^{42}$. Oto charakterystyczny tytuł wiersza napisanego z okazji srebrnego jubileuszu: Rundgesang an dem glücklich erlebten 25-jährigen Bergenschen Hochzeitsfeste gesungen von Mutter, Schwestren, Niecen und einigen Freunden ${ }^{43}$. Powstaje wszakże pytanie, czy istotnie jest to przykład pseudonimu. Czy w ogóle wchodzi tu w grę autorstwo? Może mówić należy raczej o dedykacji? Jeśli tak, problem autorstwa pozostaje otwarty - zresztą nie tylko w tym wypadku. Dedykującego nie można albo: nie zawsze można identyfikować z autorem. Lecz poczynić trzeba i tę uwagę: autorzy wybierali spośród pseudonimów najczęściej literonimy (łącząc je niekiedy z grafonimami) i kognationimy, a więc te rodzaje, które nie stanowiły dla adresatów zbyt zawiłych zagadek, przeciwnie: w odbiorze czytelniczym okazywały się łatwe do rozszyfrowania, $w$ każdym razie $w$ gronie rodziny i przyjaciół. W pewnym sensie tak dobrane pseudonimy podnosiły prywatność poezji epitalamijnej, a ponadto włączały uczestników uroczystości weselnej do gry literackiej, do której pseudonim swoją tajemniczością, niedopowiedzeniem zachęcał i zapraszał. Czyż nie należy tu mówić o związkach tej twórczości z kulturą rokoka, $z$ jego sentymentalną nastrojowością i intymnością?

Od starożytności poczynając epitalamia, różnie zresztą nazywane (carmen in nuptiis, hymenaeus, encomium nuptiale, elegia nuptialis, hymnus in nuptiis, ode, panegyris, dithyrambus), wypełniały pochwały bogów jako kreatorów małżeństwa, pochwały znanych par małżeńskich (Jowisz - Juno), rozważania o wartości i znaczeniu instytucji małżeństwa dla ludzkości (z przywołaniem postaci Menelausa i Heleny, Peleusa i Tetydy), życzenia doczekania potomstwa (z uzasadnieniem, że rodzice żyją w swoich dzieciach). Autor pamiętać również musiał o pochwale nowożeńców, o zrelacjonowaniu przebiegu uroczystości weselnych, o ich uczestnikach, krewnych, znajomych. Schemat ten obowiązywał w ciągu wielu stuleci. Powrócił do niego Scaliger, autor wspomnianego dzieła Poetices libri septem ${ }^{44}$, cenionego w okresie renesansu, a i później cieszącego się niemałym autorytetem. Według niego, epitalamium powinno obejmować następujące komponenty: opowieść o pragnieniach narzeczonego i narzeczonej, pochwałę oblubieńców (a patria, a genere, animi studiis, corporis praesentia), dobrą wróżbę, przepowiednię potomstwa, wysławianie łoża lub szaty pani młodej, ewentualnie swobodne żarty. Scaliger brał pod uwagę także inny wariant $-z$ wysławianiem zaślubin, z pochwałą małżeństwa, miłości i przyjaźni (od początku świata, od zaślubin Nieba i Ziemi), z opiewaniem zaślubin bogów i bohaterów mitycznych, z przywołaniem bogów: Marsa, Merkurego, Apollina, Wenery, Diany...

40 Ibidem, s. 134-139.

${ }^{41} \mathrm{IS}^{\star \star} \mathrm{H}^{\star *}$, Die Martens- und Soermannsche Vermählung, in Danzig, den 20. Hornung 1794 feyerlichst besungen von..., [Danzig]. Egz. BG PAN, sygn. Ms 1095 IV 15; Oe $84452^{\circ}$.

${ }^{42}$ D. Świerczyńska, op. cit., s. 112-113.

${ }^{43}$ Danzig 1798. Egz. BG PAN, sygn. Oe $828^{\circ}$ adl. 76.

44 J.C. Sclaiger, op. cit., s. 150-155. 
Zarówno w wierszach epitalamijnych jak i w utworach upamiętniających rocznicę ślubu wykształciła się charakterystyczna topika, wywodząca się ze starożytności grecko-rzymskiej i Biblii, następnie wielokrotnie powielana w okresie renesansu i baroku. Śladami idyllicznej i elegijnej poezji Teokryta i Katullusa, epitalamiów Stacjusza i Klaudiana, niekiedy także Pieśni nad Pieśniami wypełniano wiersze matrymonialne pochwałami nowożeńców i ich rodzin, także gości przybyłych na uroczystości weselne, wywodami o randze i znaczeniu małżeństwa. Zwykle jeden z tych komponentów zdobywał przewagę, dlatego mówić można o epitalamiach panegirycznych, refleksyjnych i moralizujących oraz ludycznych. W tej typologii można zresztą iść dalej $\mathrm{i}$ - przyjąwszy inne kryteria - wymienić odmianę epicką, liryczną (z pieśnią, odą weselną, hymnem i dytyrambem), retoryczno-oratorską i dramatyczno-teatralną. Dodajmy do tego jeszcze elegie i sielanki weselne ${ }^{45}$.

Gdańscy autorzy, uprawiający rodzinną poezję weselną, preferowali odmianę liryczną. Obdarzali swoich bliskich odami i pieśniami. Występowali także z sielankami i elegiami. Nie stronili od form oratorskich lub do nich zbliżonych. Zawsze jednak utworom swoim nadawali charakter wypowiedzi refleksyjnej, moralizującej - niezależnie od wybranej przez siebie struktury gatunkowej.

Oda pochodząca z roku 1749 autorstwa Karola Wilhelma Soermanna zaczyna się od rozważań na temat egoizmu i miłości, wynosząc jako wartość szczególną tę ostatnią:
Man liebt sich, wie ein Glied sich liebet, Das tausend andern Nahrung giebet, Sich regt, bewegt und lebt, so lang es andern dient...

Myśl ta powraca również w części zwróconej bezpośrednio do brata i jego wybranej:

\section{Nun möget Ihr die Wohlfahrt gründen \\ Die niemand einsam kann empfinden, \\ Die Wohlfahrt, dadurch sich die Liebe überlebt...}

W utworze, określonym przez autora mianem Schäfererzehlung ${ }^{46}$, pojawia się inny motyw: złotego wieku, wieku pokoju i bezpieczeństwa, któremu przeciwstawiano współczesność. Wspiera on wywody poświęcone małżeństwu i miłości, a także pełne krytycyzmu wobec współczesności uwagi rodzaju:

\section{Der Ekel schleicht sich oft mit Misvergnügen ein Und das getraute Paar möcht gern getrennet seyn.}

Po tych ogólnych konstatacjach następują - oparte na alegorii morskiej - refleksje i pouczenia adresowane do młodej pary:

${ }^{45}$ Por.: K. Mroczek, Epitalamium staropolskie. Między tradycją literacką a obrzędem weselnym. Wrocław 1989, s. 7-46.

46 Por. przyp. 35. 
Auch in dem Sturm der Welt kanst Du zufrieden leben, Muß gleich der Hofnung Schif auf Sorgen Wellen schweben, Sey Deinem Gott getreu, und seiner Huld gewiß, Der Menschen Leben bleibt doch voller Kümmerniß,

Und wenn bisweilen gleich die Freudenstrahlen scheinen, So laurt der Donner nur, bis daß die Wolken weinen. Die Gnade Gottes muß des Menschen Hafen seyn, In diesen senkt sein Muth der Hofnung Anker ein...

Końcowe wersy przypominają bardziej przemówienie niż sielankę; mają więcej wspólnego z genus deliberativum, z doradzaniem, moralizowaniem niż ze światem idylli.

Postać przemówienia otrzymał również inny tekst, podpisany przez Schweera, przy czym w roli oratora występuje tu brat panny młodej. Zwracając się do pana młodego zapewnia go o jej miłości, stałości w uczuciach, wierności. Tego samego oczekuje z jego strony:

Und auch Du mein Theurester, mein Bester!

Mache glücklich meine liebe Schwester,

Mache glücklich Deine Lieblingin,

Deine Liebe goldne Ihre Tage,

Deinem Lächeln schweige jede Klage,

Taumle jeden Trauerblick zurück.

W zakończeniu - bogatym w metafory - skupia się sens i cel wystąpienia:

Nun so wandelt froh durchs Erdenleben,

Fühlt die Wonne, die Euch Gott gegeben

Unbekümmert über fernen Schmerz;

Brecht die Blume, ehe sie verblühet

Euer Himmel werde Euer Herz.

I ten, i wcześniej tu przypomriane utwory należą do wypowiedzi poważnych, niosą z sobą zawsze rozważania dotyczące ludzkiej kondycji i wartości w środowisku miejsko-mieszczańskim szczególnie wysoko cenionych, takich jak pokój, poczucie bezpieczeństwa, harmonia, lojainość, wierność.

Utwory ludyczne zdarzały się nader rzadko, wszelako kilka tekstów można tu przywołać. Wspomniane już epitalamium Karola Beniamina Gottwaldta z początku wieku jest właśnie przykładem utworu radosnego, żartobliwego. Autor pisze o sobie, że usiłuje ein Freuden-Lied zu machen. Wypełnił go - wzorem antycznych i późniejszych wierszy weselnych - postaciami Kupidyna, Amora i Hymena, zaczął zaś radosnym wezwaniem: 
Weg schwartzer Trauer-Flohr, weg traurige Cypressen; Weg alles Ungemach, das uns betrüben kan...

Zakończył natomiast poważnie brzmiącymi życzeniami, by Bóg błogosławił młodej parze, czuwał nad jej drogami. Nastrój wiersza jest więc zmienny: od tonów radosnych, od żartów do słów pełnych powagi, od radosnej pieśni do oracji.

Inny przykład: wiersz darowany wujowi - Danielowi Bogumiłowi Bünsowowi przez grono jego bratanków i bratanic. Zaczyna się on od przypomnienia historii Adama i Ewy, podanej wszelako w formie żartobliwej narracji. Ewa została tu przedstawiona jako Dame Eva, Adam jako unser Großpapa:
Alles lag inm vor der Nase;
Mit Frau Eva lag im Grase
Unser Großpapa und aß
Trauben, Prasseln, Ananas.
Gelt! das war ein herrlich Leben!
Immer Pflaumen, Prasseln, Reben,
Bruder Benjamin, eya!
Eya! wären wir noch da!

Lecz wiersz przypomniał nie tylko raj, także wypędzenie z raju i jego następstwa. Ziemia stała się przestrzenią cierpien, lęków, łez. Stan ten oddał autor posłużywszy się częstym w literature, zwłaszcza w poezji refleksyjnej tego czasu motywem, słowem-kluczem: Jammerthal. Do rangi szczególnej dorastają - pośród tej przestrzeni, nieżyczliwej człowiekowi - takie wartości, jak przyjaźń i miłość. Ich pochwale poświęcona jest dalsza część wiersza, nie pozbawiona zresztą także elementów żartobliwych:

Lebe, Vielgeliebtes Pärchen, So ein fünf und achzig Järchen, Unter Küssen, Scherz und Wein, Heiter in die Welt hinein.

\section{Söhne, Töchter und Dukaten \\ Gäb Euch Gott, und Fisch und Braten! - Uebrigens bleibt uns fortan Stets in Freundschaft zugethan!}

Inaczej pomyślany został wiersz dedykowany przez młodą parę, Karola Gabriela Schmidta i Dorotę Luizę Schnasse, gościom weselnym. Bohaterowie uroczystości - stosownie do obyczaju - postanowili obdarzyć swoich gości okolicznościowym druczkiem, opublikowanym w gdańskiej oficynie Wedla ${ }^{47}$, nie wykona-

\footnotetext{
${ }^{47}$ Daniel Ludwik Wedel (1730-1822) był księgarzem, nakładcą i właścicielem drukarni działającym
} w Gdańsku od 1761 roku. 
nym jednak, co zaznaczyli, kunsztownie, na jedwabiu, lecz na skromnym białym papierze:

\author{
Statt Bänder, so wie gebräuchlich, von Seide, \\ erscheint hier ein Liedchen im schmucklosem Kleide, \\ auf wenige Blätter von weißem Papier \\ gedruckt mit Wedelschen Schriften allhier.
}

W kilkunastu czterowersowych zwrotkach, w sposób wyszukany zbudowanych - dwa początkowe wersy składają się z czterech amfibrachów, dwa pozostałe z trzech amfibrachów i jednego jambu - snuje się opowieść o przebiegu uroczystości weselnej, ale widzianej przez młodą parę we śnie. Czytelnik dowiaduje się o nastrojach wśród gości, młodych i starych, o zabawach (na przykład o grze w fanty), o uczcie:

Wir assen, und tranken, und freuten uns sehr, und sangen: wenn's immer, wenn's immer so wär!

Opowieść została doprowadzona do końca, to znaczy do momentu, gdy goście odprowadzają młodą parę do domu:

Und als er's gelesen, da wurde mit Singen, mit Lachen und Scherzen, mit Tanzen und Springen, das Brautpaar von Allen nach Hause gebracht, und hiemit dem Traume ein Ende gemacht.

Całość zamyka strofa tworząca wraz z pierwszą zwrotką ramę utworu:

Dieß ist nun das Liedchen im schmucklosen Kleide, gedruckt statt der glänzenden Bänder von Seide, wenn gleich nicht auf Atlas noch Schweizerpapier, doch deutlich mit Wedelschen Schriften allhier.

Utwór należy niewątpliwie do epickiej odmiany poezji epitalamijnej, odbiega jednak od przyjętych schematów, przynosi bowiem żartobliwą opowieść lub pieśń - bardzo zresztą rytmiczną - o uroczystości, pozbawioną tego, co było dla tej odmiany wierszy weselnych charakterystyczne: prezentacji państwa młodych i gości, czemu niekiedy towarzyszyły paralelnie rozwijane narracje antyczne z udziałem postaci mitologicznych. Intencją autorów było wystąpić właśnie z żartobliwą relacją, a nie z patetyczną opowieścią czy pieśnią. Jesteśmy znowu w kręgu sztuki rokokowej. Podziwiamy wdzięk, lekkość słowa, grę z czytelnikiem.

$Z$ inicjatywy członków rodzin powstawały również wiersze na rocznicę ślubu. Wśród twórców lub tylko autorów dedykacji były przede wszystkim dzieci obcho- 
dzących srebrny lub złoty ${ }^{48}$ jubileusz małżeństwa ${ }^{49}$, niekiedy wyłącznie syn ${ }^{50}$ lub - przeciwnie - cała rodzina ${ }^{51}$, ale życzenia składała także wahre Freundin ${ }^{52}$, co nie było bynajmniej wypadkiem wyjątkowym. Zresztą grono domowników w najszerszym tego słowa znaczeniu, grono przyjaciół było wśród autorów (częściej pewnie tylko dedykujących lub podpisujących utwory epitalamijne) bardzo szerokie. Raz po raz ujawniał się przyjaciel domu: ungenannter Freund. Bardzo często podpisywali się pod epitalamiami - jak w wypadku genetliakonów i wierszy na rocznice diei natalis - verbundener Diener, Dienst Bereitwilligster, Tief Ergebenster, Tieff-verbundenster, tiefverplichtester Diener, ergebener Diener ${ }^{53}$. Zdarzały się też dość tajemniczo brzmiące prezentacje: ungenannte doch wohlbekannte Gönnerin albo ein ungenannter Freund.

Niezależnie od tego, czy wiersze na cześć jubilatów powstawały w najściślejszym gronie rodzinnym, czy też były dziełem szeroko rozumianych domowników, przyjaciół, miały one wiele cech wspólnych, powielały tę samą topikę. Łączy je najczęściej retoryczno-oratorski schemat kompozycyjny (choć oczywiście o odstępstwach od tej normy zawsze można mówić). Dość przyjrzeć się części wstępnej, w której zawsze doszukać się można toposów ab auditorum persona lub ab rebus ipsis, i zakończeniu, z reguły będącemu pointą wypełniającej utwór pochwały,

\footnotetext{
${ }^{48}$ Warto zwrócić uwagę, że utworami epitalamijnymi czczono nie tylko srebrne i złote wesele, lecz także na przykład 17-czy 38-lecie małżeństwa.

${ }^{49}$ Unsern theuersten Eltern bei der Feier Ihres Silberhochzeitsfestes gewidmet von sämmtlichen Kindern, Danzig 1797. Egz. BG PAN, sygn. Oe $828^{\circ}$ adl. 20; Unsern theuersten Eltern bei der Feier Ihres Silberhochzeitsfestes den 19. Merz 1797 von Ihren Kindern gewidmet, Danzig [1797]. Egz. BG PAN, sygn. Oe $828^{\circ}$ adl. 23; D. R. und P. Dodenhoff, Unsern theuresten Eltern an Ihren Kindern Fünf und Zwanzig-jährigen Hochzeitsfeste von.... Am 9. Junius 1799, [Danzig 1799. Egz. BG PAN, sygn. Oe $828^{\circ}$ adl. 89; Empfindungen bey dem Silberfeste unserer werthen Eltern. Den 5. December 1790, Danzig [1790]. Egz. BG PAN, sygn. Oe $818^{\circ}$ adl. 27.

${ }^{50}$ Ernst Gottlieb Lilienthal, der Weltweißheit Beflißner, Dem acht und dreyßigsten Hochzeit-Tage des [...] Herrn Heinrich Soermanns, Commissairs Ihro Hochmögenden der Herren General - Staaten, und der Wohlgebohrnen Frauen, Frauen Anna Maria gebohr. Rammelmannin widmet diese Zeilen und empfiehlet sich nebst seinen Aeltern zu beständigem geneigten Andenken [...]. Danzig, den 20ten Februarii 1758, [Danzig 1758]. Egz. BG PAN, sygn. Ms 1095 IV 57; Oe $642^{\circ}$ adl. 95; Johann Gottfried Engelmann, Seinem Hochzuverehrenden Herrn Vater Herm Christian Gottlob Engelmann wie auch seiner Hochzuverehrenden Frau Mutter Frau Eva Concordia geb. Hadeschlief widrnete dieses an Ihrem Gold-Hochzeitfeste, welches den 19. October 1784 zu Thoren feyerlich begangen wurde, ein höchstverpflichteter Sohn..., Danzig [1784]. Egz. BG PAN, sygn. Oe $818^{\circ}$ adl. 10.

${ }^{51}$ Zum freundschaftlichen Andenken an die 17ten mal erneuerte Hochzeitsfeyer gewidmet von der Familie. Den 14ten März 1796, Danzig [1796]. Egz. BG PAN, sygn. Oe $818^{\circ}$ adl. 41.

${ }^{52}$ L. C. K., Der Hahnschen Silberhochzeitfeyer gewidmet von Ihrer wahren Freundin... Danzig, den 19. Merz 1797, [Danzig 1797]. Egz. BG PAN, sygn. Oe $828^{\circ}$ adl. 24.

${ }^{53}$ Der Herr in der Ehe, an Herrn George Thomas Osterroht und Seine Herzlichgeliebte Ehgattin bey dem rühmlichen Gedächtnis-Tage welcher zum Preiß und Ehre des Schöpfers Ihrer seit 25 Jahr beständig vergnügten und gesegneten Ehe den 3ten Julii 1757 mit schuldigster Aufmerksamkeit betrachtet wurde von einem aufrichtigen Diener, Danzig [1757]. Egz. BG PAN, sygn. Oe $642^{\circ}$ adl. 83; Gedanken welche bey dem den 2ten Weinmonats 1757 in Danzig durch Gottes Gnade glücklicherlebten fünf und zwanzigsten Jahr einer vergnügt-geführten Ehe des [...] Herrn Johann Gottlieb Schott, Wohlangesehenen Kauf-und Handels-Manns und Der [...] Frauen Regina Schottin, geb. Müllerin, um seine inbrünstige Mitfreude zu bezeigen entflossen Ihrem Ergebenen Diener, Danzig [1757]. Egz. BG PAN, sygn. Oe $642^{\circ}$ adl. 90.
} 
pointą wyrażającą sympatię dla jubilatów i ich gości. Jeden charakterystyczny przykład zamykający w sobie życzenia - pełne czułości, z licznymi deminutivami adresowane do obchodzących w dniu 4 marca 1796 roku 17-lecie (może 14-lecie ${ }^{54}$ ) swego małżeństwa:

Einst versammeln wir uns, das Fest des Jubels zu feyerr, Dann erhebt sich vielleicht in unsre frohen Gesänge

Auch ein freundliches Stimmchen, ein Wörtchen des lachendes Enkels.

Nie tylko partie wstępne i zakończenia zostały ukształtowane zgodnie z regułami retorycznymi. Autorom rocznicowych epitalamiów jako wzór przyświecała, co zrozumiałe, pochwalna odmiana sztuki oratorskiej (genus demonstrativum), a ich zasadniczą część - laudację - budowały różne loci communes, jakkolwiek, trzeba $i$ to zauważyć, pomijano, podobnie jak w epitalamiach matrymonialnych, toposy odnoszące się do osoby, do tego, co było z nią związane, a w retoryce nosiło miano genus, natio, patria, habitus corporis, fortuna, conditionis instantia. Mimo to zarówno nadawca wypowiedzi jak i jej adresat byli zawsze wystarczająco wyraźnie wskazani, w każdym razie na tyle wyraźnie, by czytelna stała się relacja między nimi. Niektórzy - zarówno nadawcy jak i adresaci - są nam znani z imienia i nazwiska, inni nie zostali równie dokładnie przedstawieni. Oto $z$ karty tytułowej jednego z epitalamiów viynika, że w dniu 19 października 1784 roku złote gody obchodzili w Toruniu Krystian Bogusław Engelmann i Ewa Konkordia z domu Haderschlief, a okolicznościowy wiersz - opublikowany w Gdańsku w oficynie Wedla - dedykowat im syn Jan Gotfryd Engelmann ${ }^{55}$. W innych wypadkach wypowiadający się $w$ wierszu podmiot może być wprawdzie utożsamiany na przykład $z$ synem, z dziećmi, a nawet z szerszą zbiorowością, z całą rodzina, lecz o jego konkretyzacji - nazwijmy to tak: biograficznej - nie sposób mówić, skoro nie dysponujemy ani imieniem, ani nazwiskiem. Tę samą uwagę odnieść trzeba do adresata. Pozostaje on często do końca anonimem, nie wymienia się bowiem ani jego imienia, ani nazwiska, określona natomiast jest jego relacja w stosunku do nadawcy i vice versa; znana jest również atmosfera uczuciowa otaczająca obu. W końcu w wypadku poezji rodzinnej najważniejsza była intymność, prywatność, a nie konwencja oficjalności.

Mając wszystko to w pamięci, stwierdzić wszakże możemy, iż jest pełne uzasadnienie, by mówić o podmiocie ujawnionym, nie ukrywa on bowiem swoich uczuć, przekonań, opinii. Oto przykład:

\section{Uns Kinder, die Euch Gott gegeben, Habt Ihr ganzer Seel geliebt, und uns, stets tugendhaft zu leben, von früher Kindheit an geübt; doch stets ging auf der Tugendbahn Ihr Euren Kindern selbst voran.}

${ }^{54}$ Por. egz. BG PAN, sygn. Oe $818^{\circ}$ adl. 41: na karcie tytułowej mowa o 17-leciu ślubu, natomiast utwór zaczyna się od stów: „Vierzehn Jahre sind heut dahingeflohen...”.

${ }^{55}$ Egz. BG PAN, sygn. Oe $818^{\circ}$ adl. 10. 
I jeszcze jeden przykład:

\author{
Jetzt blühet Ihr in Eurer Kinder Mitte \\ geehret und geliebt, \\ denn Ihr, beherrscht von edler Herzensgüte, \\ habt keinen je betrübt.
}

So blüht ein Baum, wo Kühlung, Ruh und Schatten und süsse Labefrucht

ein Wanderer bei schwüler Zeit mit matten und müden Schritten sucht:

So findet Rath und Hülfe, wer gedrükket von bangen Sorgen ist;

durch Rath und Tath habe manchen Ihr erquikket, durch Trost sein Leid versüßt.

Powyższe cytaty najlepiej świadczą o powiązaniu wierszy, z których one pochodzą, z tradycją retoryczną, z przynależnością do tego modelu oratorstwa, który kojarzymy z genus demonstrativum. Nie można jednak nie dostrzec związków także $z$ genus deliberativum, a więc $z$ oratorstwem refleksyjnym, nastawionym na zalecanie, zachęcanie, doradzania, odradzanie, rozważanie, moralizowanie. Powołać się tu można głównie na partie, w których powraca myśl o przemijaniu:

Von der ersten Kindheit an Gehen wir mit vollen Schritten, Auf der uns bestimmten Bahn, Zu des ernsten Alters Mitten.

Schreiten wir nun weiter fort Bis wir endlich Greise werden, Wo uns an so manchen Ort Schon erwarten viel Beschwerden...

Wszystko w porządku świata podlega zmianom; tę prawdę - według wielu autorów - odnieść należy w jednakowym stopniu do jubilatów, jak i wszystkich uczestników uroczystości weselnej sprzed lat:

Die einst Mädchen waren und gern der Blume sich freuten, Wenn sie am keuschen Busen und auf den Locken der Stirne Blühten zum festlichen Schmuck - sind Frauen und Mütter geworden...

W epitalamiach wspomina się nieżyjących już uczestników uroczystości sprzed ćwierćwiecza, a nawet półwiecza. Przeszłość i teraźniejszość stale się tu spoty- 
kają. Autorzy wracają do lat wspólnie przez jubilatów przeżytych - zawsze w kontekście rozważań o przemijaniu i zmienności wszystkiego. Natomiast jako wartość stała jest w tych wierszach traktowana miłość, jaką dzieci, wszyscy bliscy żywią wobec nich. Stała jest też wdzięczność dzieci za ofiarowane im życie, za troskliwość, za wychowanie, za dany im przykład życia. Te motywy są obecne we wszystkich wierszach napisanych przez dzieci lub powstałych $z$ ich inspiracji. I w tych epitalamiach, i w innych, których geneza łączy się z dalszą rodziną, z przyjaciółmi domu, jako trwałe komponenty pojawiają się również gratulacje i życzenia. Ważne miejsce zajmuje w nich również pochwała dnia srebrnego czy złotego wesela, dnia radości jubilatów i ich najbliższych, dnia wspomnień i dnia zachęcającego do zaintonowania laudacyjnej pieśni:

\title{
Der frohe Tag kehrt heute wieder...
}

Ten motyw powraca w wielu wierszach i ma swój udział w wyznaczeniu poetyki epitalamiów rocznicowych. Przyjmuje niekiedy kształt bardziej rozbudowany:

\author{
Dieser Tag erinnert Sie \\ An den Bund, den Sie geschlossen \\ Und der Liebe, die Sie früh \\ Mit einander schon genossen.
}

Jakkolwiek utwory jubileuszowe wyrastają w znacznej mierze z tradycji retoryczno-oratorskiej, łącząc $w$ sobie elementy generis demonstrativi i generis deliberativi, to jednak ujawniają również silne związki z liryką pieśniową, o czym w niektórych wierszach mówi się wprost:
Wir, wir Kinder stimmen ein
Und die Enkel hallen wieder,
Singen alle insgemein
Gott dem Höchsten frohe Lieder.

I kolejny przykład:
Zum frohen festlichen Gesange sind, Theure Eltern, wir vereint; die Freude röthet unsre Wange, von frohen Thränen naß geweint; sie ist es, die uns heut durchglüht, und die beseelet unser Lied.

W tym kontekście warto przypomnieć - raz tu już wymieniony - utwór noszący tytuł: Rundgesang an dem glücklich erlebten 25-jährigen Bergenschen Hochzeit- 
sfeste gesungen von Mutter, Schwestren, Niecen und einigen Freunden ${ }^{56}$. Jest to tekst rozpisany na głosy, przeznaczony do chóralnego i solowego wykonania na melodię (co zostało podane): Ey, wo sind die Veilchen hin.

Rytm wiersza, jego melodyjność, podział na zwrotki, nade wszystko zaś wdzięk, delikatność i lekkość, niewątpliwa gra intelektualna prowadzona przez autora z czytelnikiem, czułość łącząca w sobie wrażliwość zmysłową z emocjonalną, każą utwór ten i inne tego pokroju sytuować bodaj pośród dzieł poezji rokokowej. Dodajmy do tego graficzne wyposażenie druczków epitalamijnych, skromne wprawdzie, ale przecież wykorzystujące typowo rokokowe motywy kwiatów, wodorostów, girland, atrybuty miłości z amorkami czy serduszkami.

Nie powiemy tego o epitalamiach pisanych na rocznicę ślubu przez przyjaciół, przez tych wszystkich, którzy podpisywali się jako aufrichtiger Diener lub ergebener Diener. Autorzy ci tworzyli w duchu retoryczno-oratorskiej konwencji, oscylowali między genus demonstrativum i genus deliberativum - w trosce zapewne o oficjalny kształt swej poetyckiej wypowiedzi, o jej monumentalność. Niech zjawisko to zilustruje zakończenie wiersza pochodzącego z 1757 roku, a dedykowanego Janowi Bogumiłowi Schottowi i jego małżonce Reginie z domu Müller ${ }^{57}$ :

\section{Liebt Euch geschätztes Paar, bis Euer Sterbekissen \\ Euch Beyden Leib und Athem nimmt. \\ Doch wachse lange nicht der Stein, der Eure Decke \\ Des Grubes obre Zierde sey, \\ Und so, daß keine Pein Eur Todtenlager schrecke, \\ Damit Eur Diener sich erfreu.}

Monumentalność, o której tutaj mówimy, silniej niż w wierszach epitalamijnych ujawniła się w epitafiach i epicediach, stanowiących kolejną cząstkę poezji rodzinnej. Trzeba jednak od razu zauważyć, że prezentuje się ona liczbowo skromnie. Trudno dziś wskazać utwory - może się nie zachowały? - w których ojciec opłakiwałby dziecko, mąż - żonę, brat - brata lub siostrę, syn ojca czy matkę. Trudno o nie, ale na kilka przykładów będziemy się mogli powołać. Jedno zdaje się nie ulegać wątpliwości: wśród autorów byli raczej dalsi krewni, przyjaciele domu, ci wszyscy, którzy na karcie tytułowej przedstawiali się jako unterthäniger Diener ${ }^{58}$,

\footnotetext{
${ }^{56}$ Por. przyp. 42.

${ }^{57}$ Gedanken welche bey dem den 2ten Weinmonats 1757 in Danzig durch Gottes Gnade glüklicherlebten fünf und zwanzigsten Jahr einer vergnügt-geführten Ehe des [...] Herrn Johann Gottlieb Schott, Wohlangesehenen Kauf- und Handels-Manns und Der [...] Frauen Regina Schottin, geb, Müllerin, um seine inbrünstige Mitfreude zu bezeigen entflossen Ihrem Ergebenen Diener, Danzig [1757]. Egz. BG PAN, sygn. Oe $642^{\circ}$ adl. 90. Wymienić - tytułem przykładu - można jeszcze inny utwór: Der Herr in der Ehe, an Herrn George Thomas Osterroht und Seine Herzlichgeliebte Ehgattin bey dem rühmlichen Gedächtnis-Tage welcher zum Preiß und Ehre des Schöpfers Ihrer seit 25 Jahr beständig vergnügten und gesegneten Ehe den 3ten Julii 1757 mit schuldigster Aufmerksamkeit betrachtet wurde von einem aufrichtigen Diener, Danzig [1757]. Egz. BG PAN, sygn. Oe $642^{\circ}$ adl. 83.

${ }^{58}$ J. G. D., d[er] G[ottesgelartheit] B[eflissener], Bey dem Grabe der Weyland [...] Jungfer Sara Florentina Buchanin, des [...] Herrn Jacob Buchan, ältesten Diaconi bey der St. Peter und Pauli Kirche ältesten Jungfer Tochter wollte seine Leyd-Wesen denen Vornehmen betrübten Angehörigen
} 
Ergebenster ${ }^{59}$, ergebener Diener ${ }^{60}$. I znowu spotykamy się z pseudonimami, zwłaszcza z literonimami, będącymi najprawdopodobniej inicjałami imion i nazwisk autorów (w niektórych wypadkach tylko nazwiska lub tylko imienia ${ }^{61}$ ), i kognationimami w rodzaju: „zwee gute Freunde $S$. und G." ${ }^{62}$, nie zawsze - jak w tym wypadku - określającymi stosunek pokrewieństwa, częściej przyjaźni. Obecność pseudonimów w poezji żałobnej nie służy, oczywiście, grze literackiej jak w epitalamiach, lecz wyraża przede wszystkim bardzo osobisty stosunek do zmarłego i jego najbliższych, skromność piszącego, dla którego uczczenie pamięci zmarłego było ważniejsze niż demonstrowanie własnego autorstwa. To właśnie upoważnia nas do włączenia tych utworów w krąg twórczości rodzinnej. Naturalnie nie tylko tych - pióra przyjaciół domu - ale również, a właściwie przede wszystkim, powstałych z inspiracji krewnych, najczęściej przez nich samych napisanych. Można tu przykładowo wymienić wiersz Samuela Bogumiła Weickhmanna opublikowany - zresztą w Lipsku - po śmierci jego stryja, Bogumiła Gabriela Weickhmanna (1708-1776), burmistrza Gdańska ${ }^{63}$, albo o kilkanaście lat wcześniejsze epicedium pióra Beniamina Benedykta Henrichsdorffa poświęcone Eleonorze Konstancji Löbel z domu Henrichsdorff - może siostrze autora? ${ }^{64}$ Dalsze przykłady. Jeden z początku wieku. Podczas uroczystości pogrzebowych Krystiana Schrödera (1626-1701), długoletniego burmistrza Gdańska, kazanie w kościele NMP wygłosił Samuel Schelwig (1643-1715), rektor Gimnazjum Gdańskiego i pastor kościoła Św. Trójcy. Do opublikowanego później tekstu tego kazania ${ }^{65}$ dodano kilkanaście epi-

in aller Ergebenheit an den Tag legen ein unterthänigster Diener [...] Danzig 1763, den 20. November, [Danzig 1763]. Egz. BG PAN, sygn. Oe $552^{\circ}$ adl.10; G.F.L., Klage-Ode bey dem schmertzlichen Hintritt des [...] Herrn Abraham Clemens Jungen Sohnes widmete folgende Zeilen zum Zeichen seiner Hochachtung ein unterthäniger Diener [...]. Danzig, den 20ten Augusti 1757, [Daznig 1757]. Egz. BG PAN, sygn. Oe $552^{\circ}$ adl. 16.

${ }^{59}$ Dem [...] Herrn Abraham Clemens, Hochverdienten Vorsteher der St. Peters Kirche widmete bey dem frühen Verluste seines einzigen Sohnes folgende Klag-Ode ein Ergebenster, Danzig 1757. Egz. BG PAN, sygn. Oe $552^{\circ}$ adl. 17.

${ }^{6}$ D. C. H., Als den [...] Herrn Abraham Clemens, Berühmten Kaut-und Handelsmann, wie auch Hochverdientes Mittglied eines hochansehnlichen Comercien-Collegi, bey dem frühzeitigen Hintritt seines Hofnungsvollen Sohnes von einem ergebenen Diener, [Danzig 1757]. Egz. BG PAN, sygn. Oe $552^{\circ}$ adl. 18.

${ }^{61}$ R., Bey dem Grabe des [...] Herrn Gottfied Meyer, Hochverdient-gewesenen Rahtsverwandten derRechten Stadt, widmete Denen vornehmen Leydtragenden folgende Zeilen ein ergebenster Diener... Im Jahr 1754, den 3. September, Danzig [1754]. Egz. BG PAN, sygn. Oe $85734^{\circ}$.

${ }^{2} \mathrm{~S}$. und G., Trauer-Gedicht. Dem Andenken der [...] Frauen Susanna Maria Weißschnur gebohrne de la Portin gewidmet von zween guten Freunden... Danzig, den 10ten Januar 1765, [Danzig 1765]. Egz. BG PAN, sygn. Oe $552^{\circ}$ adl. 79.

${ }^{63}$ S.G. Weickhmann, d[er] G[ottesgelahrtheit] B[eflissener], Auf den Tod seines Verehrungswürdigsten Onkels, des [...] Herrn Gottlieb Gabriel Weickhmann, weiland Höchstverdienten Bürgermeisters zu Danzig und Administrators des Höhischen Gebiets, Leipzig [1776]. Egz. BG PAN, sygn. Oe $112312^{\circ}$.

${ }^{64}$ B.B. Henrichsdorff, der Gottesgelahrtheit Beflissener, Bey dem Grabe der [...] Frauen Eleonora Constantia Löbel, gebohrn. Hennichsdorff, überreichte diese Zeilen ein verbundenster Diener [...] Danzig, den 10. des Herbstmonats 1756, [Danzig 1756]. Egz. BG PAN, sygn. Oe $552^{\circ}$ adl. 46.

${ }^{65}$ Samuel Schelwig [...], Gott unser wir Gottes, das ist Christliche Erklährung der Worte aus dem 91. Psalm [...], welche bey [...] Leich-Begängniß des Weiland [...] Herrn Christiani Schröders, gewesenen ältesten Burgermeisters, Proto-Scholarchae, Ober-Administratoris des Stüblauischen Wer- 
cediów, a ich autorami byli między innymi Jerzy Schröder i Jan Ernest Schröder ${ }^{66}$, niewątpliwie należący do najbliższych zmarłego. Praktyka dodawania do edycji kazania epicediów była w Gdańsku dość powszechna. Kolejny przykład - tym razem z połowy wieku. Po śmierci Jakuba Henryka Zerneckego (1672-1741), burmistrza toruńskiego, który koniec swego życia spędził w mieście nad Motława, kazanie pogrzebowe wygłosił pastor kościoła Św. Katarzyny Bogumił Richter (1648-1752). I ono - w momencie wydania ${ }^{67}$ - zostało uzupełnione o kilkanaście epitafiów i epicediów. Wśród ich autorów byli syn zmarłego, Henryk, i wnuk, Jan Henryk ${ }^{68}$, który wystąpił również w imieniu swego rodzeństwa - Eleonory Konkordii i Karola Jakuba. Tenże kaznodzieja żegnał diakona kościoła Św. Katarzyny, Jana Daniela Unselta (1690-1742), i jego synka, Walentego Gabriela. Tekst kazania został opublikowany ${ }^{69}$, a dołączone do niego zostały liczne epicedia - pióra między innymi członków rodziny. Byli wśród nich bracia stryjeczni zmarłego, Jan Filip i Filip Jakub Unseltowie ze Strasburga w Alzacji. Pierwszy z nich był kaznodzieją, drugi sekretarzem tamtejszych szpitali. Nigdy się z diakonem gdańskim osobiście nie spotkali, niemniej poczuwali się do więzi z nim i dali jej wyraz przesyłając do Gdańska swe funeralne wiersze. Dołączył do nich trzeci, Jan, duchowny, również z Alzacji, spod Strasburga. Zbiorek ten zamyka epicedium podpisane przez synów zmarłego: Jana Idziego, Jana Filipa i Samuela Fryderyka.

Gdańska rodzinna poezja żałobna przyjmowała postać epitafiów, a więc miniatur literackich, i bodaj jeszcze częściej epicediów, różnie zresztą nazywanych carmen funebre czy naenia, zawsze jednak mających formę obszerniejszych poematów czy pieśni żałobnych.

Epitafium przynosiło - zgodnie z wielowiekową tradycją - elementarne, przeważnie $w$ tytule zawarte, wiadomości o zmarłym, jego imię i nazwisko, wiek, a ponadto pochwałę jego zalet, wyliczenie zasług. Przybierało najczęściej formę narracyjną, rzadziej dialogową. Epitafium rodzinne - trzeba to podkreślić - było

ders, wie auch zur Zeit Krieges-Praesidentens in Danzig, welcher im Jahr 1701, den 27. Aprilis seelig in dem Herrn verschieden und den 19ten Maji hierauff [...] zur Erden bestattet worden in der PfarrKirchen zu S. Marien abgeleget und auff Begehren zum Druck außgefertiget..., Dantzig [1701]. Egz. BG PAN, sygn. Oe $982^{\circ}$ adl 1.

${ }^{66}$ Obaj zamieścili w tym zbiorku tacińskie epicedia.

${ }^{67}$ Gottlieb Richter, Pastor an der Altstädtschen Pfarr-Kirchen zu St. Catharinen, Gott, als der Glaübigen beständige Zuflucht in der Noth, hat als der weyland [...] Herr Jacob Heinrich Zernecke, Hochverdient gewesener Bürgermeister der Königlichen Stadt Thorn, den 28 Octobr. Anno 1741 in Dantzig nach fast 17 Jährigen Auffenthalt alhier, im wahren Glauben seelig entschlaffen, und darauf die entseelten Gebeine den 21 Novembr. Standesmässig [...] nach der Ober-Pfarr-Kirchen zu St. Marien zu Ihrer Grabes Ruhe gebracht wurden, aus Dessen selbst-erwehltem Leichen-Text Psalm $\mathrm{XCl} .14,15,16$ in oberwehnter Kirchen fürgestellet..., Dantzig 1742. Egz. BG PAN, sygn. Oe $952^{\circ}$ adl. 4 ; Oe $116972^{\circ}$.

${ }^{66}$ Syn napisał swoje epicedium po tacinie, wnuk - po niemiecku.

${ }^{69}$ Gottlieb Richter, Pastor zu St. Catharinen, Als ein Fürbild der Gläubigen [...] ward der weyland [...] Herr Johann Daniel Unselt, Wohlverdient gewesener ältester Diaconus bey der Altstädtischen Pfarr-Gemeine zu St. Catharinen in Dantzig, welcher den 1 April 1742 [...] im Herrn selig entschlafen und darauf nebst einem Söhnlein, Namens Valentin Gabriel, welches den 11 April verstorben, den 17 April [...] zum Grabe getragen ward, [...] fürgestellet von..., Dantzig 1743. Egz. BG PAN, sygn. Oe $952^{\circ}$ adl 5 . 
wypowiedzią często bardzo osobistą, nie wolną od wspomnień. Na zasadzie partis pro toto przytoczymy tu utwór wymienionego już Jana Filipa Unselta ze Strasburga:

Das nahe Freundschafts-Band, das Dich und mich verbunden, Hochselger, machte wir viel recht vergnügte Stunden. Mein Hertz erfreute sich, wann ich an Dich gedacht, Wenn man mir einen Brief von Deiner Hand gebracht, Nun aber habe ich mit grossem Schmertz vernommen, Daß Dein erblaßter Leib ins finstre Grab gekommen. Ach allzufrüher Tod! doch hat es Gott gethan. Es ist mir leid um Dich, mein Bruder Jonathan! Gott tröste Deine Seel, und wolle Deinen Kindern Das zugestoßene Kreutz, wie auch der Wittwelindern! Dies setze der ich alt, und jeztz ein Wittwer bin, Zu Deinem steten Ruhm, auf Deinen Grab-Stein hin.

Epitafium było wypowiedzią zwięzłą, liczącą kilka, kilkanaście wersów, epicedium natomiast należało do form znacznie bardziej rozbudowanych. Wyróżniano jego retoryczno-epicką odmianę ( $z$ rozwiniętą narracją), dalej - liryczną, przyjmującą często postać elegijnej skargi, lamentu. Zdarzały się też dialogi. Wszystkie te odmiany łączyły trzy ważne komponenty: laudatio, comploratio i consolatio. $W$ tych formach wypowiadali się twórcy poezji funeralnej niezależnie od tego, czy należeli do grona rodziny zmarłego, czy też pozostawali poza nim. Lecz rodzinny charakter utworów wycisnął - jak się wydaje w sposób dość znaczący - swoje

piętno na ich strukturze, co ujawniło się szczególnie w potraktowaniu właśnie części lamentacyjnej, komploracyjnej i konsolacyjnej.

Najbardziej rozwiniętą częścią okazała się comploratio. Opłakiwano w niej zmarłego i ukazywano ogrom żalu, smutku (luctus). Wnuk toruńskiego burmistrza, Jan Henryk Zernecke, zaczął swoje epicedium od słów:

Erblaßter Groß-Papa! was sollen wir jetzt sagen?

Wir müssen höchstbetrübt bey Deinem Grabe klagen.

Samuel Bogumił Weickhmann, przebywający w chwili śmierci stryja w Lipsku, zaczął również od komploracji:

Auch fern von jenem Leichensteine,

Der Dein Gebeine deckt;

Beb ich betrübt und weine,

Daß uns Dein Grab zu frühe schreckt.

Już z tych cytatów wnosić można, jak ważne miejsce zajmował w epicediach opłakujący - jako podmiot skonkretyzowany, biograficznie określony, przeżywa- 
jący i wyrażający swoje uczucia jako członek rodziny. Raz jeszcze Jan Henryk Zernecke, zabierający głos - przypomnijmy - także w imieniu swego rodzeństwa:

Wir dachten, Deiner Huld noch lange zu geniessen; Und unser Thränen-Fluß muß sich so bald ergiessen?

Ach! ach! Dein Todes-Fall bricht Deiner Enckel Hertz. O gar zu herbes Leid! o gar zu grosser Schmertz!

Podobnie pomyślany został podmiot w wierszu Weickhmanna, także wówczas, gdy formułował swoje myśli w pierwszej i drugiej osobie liczby mnogiej:

Ein nie gefühlter Schmerz und bange Furcht durchdringen

Die Würdigsten. - Ihr klagt in Wehmuthsvollen Zähren

Die Ihr an diesem Grabe weint, Den Gatten, Vater, Bruder, Freund, Die Freude Eurer Tage zu entbehren, Ihn, der so zärtlich Euch geliebt. Ihr klagt - und diese laute Klagen Sind viel zu schwach, nur einen Theil von dem zu sagen, Wie sehr Euch Sein Verlust betrübt.

Die Enkel wünschen Ihn mit innigem Verlangen Zurück, und fühlen ganz den schreckenden Verlust;

Statt Freude nagt Betrübniß ihre junge Brust, Und Ihr - mit Thränen trocknet Ihr der Enkel Wangen...

Uderza $w$ rodzinnych epicediach daleko idąca redukcja jednego $z$ trzech ważnych komponentów tego rodzaju utworów: pochwały. Tradycyjnie laudatio obejmowała laudes (pochwały) i iacturae demonstratio (ukazanie starty). Wyliczano tu cechy charakteru zmarłego, zwłaszcza jego zalety, jego zasługi. Ukazywano go pośród rodziny, od strony roli, jaką w rodzinie pełnił. Próbowano odpowiedzieć na pytanie o to, co wnosił do życia rodzinnego. Tak powstawał portret zmarłego, często uwznioślony. Lecz w gdańskich epicediach rodzinnych - podkreślmy raz jeszcze - dominuje comploratio, natomiast laudatio znajduje się na dalszym planie. O zasługach burmistrza Bogumiła Gabriela Weickhmanna jego bratanek wprawdzie wspominał, lecz w strukturze raczej komploracji, a nie laudacji, co od razu określiło rangę i miejsce pochwały $w$ całym epicedium:

Ihn, Danzigs besten Vater zu verlieren, Wie sollte dies nicht Patrioten rühren?

Sie sehen Danzigs Säule fallen, Und Klagelieder schallen Durch die gedrängte Luft. 
Podobnie w wierszu Jana Unselta, duchownego spod Strasburga, który zwrócił się do zmarłego diakona kościoła Św. Katarzyny w następujących słowach:

Dein Dantzig weint um Dich, und muß mit Wehmuth sagen:

Der Lehrer stribt, der uns die Himmels-Wege wieß...

Z kolei synowie Unselta pisali - również w granicach comploratio - o ojcowskiej miłości:

So zart auch unser Geist bey frühen Kindheits-Jahren, So kräncket uns doch schon der schmertzliche Verlust Den wir durch Deinen Tod, Wohlseliger, erfahren. Wir tragen insgesamt Dein Bild in unsrer Brust, Ein Bild der Zärtlichkeit und reinsten Vater-Liebe, Wir wissen wie Du uns, versorget und gepfegt; Wie Deine Freundlichkeit so viel gerechte Triebe Zur Ehrfurcht gegen Dich, entflammet und erregt. Dies alles wird uns nun mehr als zu früh entrissen, Da Dich des Todes Streich in Sand und Staub verkehrt.

Analogiczną laudację znajdziemy w innych epicediach. Powracały w nich zwłaszcza pochwały męża i ojca, żony i matki, ich roli w rodzinie, ich troskliwości.

Skromne miejsce pochwały - przypomnijmy: $z$ reguły w granicach comploratio - oznaczało odejście od instytucjonalnego traktowania śmierci i zmarłego. W rodzinnej poezji funeralnej nie do przyjęcia była wypowiedź oficjalna z oceną stylu życia zmarłego, całego systemu wartości przez niego wyznawanych. Autorzy koncentrowali się na sprawach eschatologicznych, na rozmyślaniach o śmierci, i to bardzo osobiście traktowanych. Nierzadko włączali do nich wspomnienia związane z osobą zmarłego. Śmierć rozważali właściwie niezależnie od życia. Wszak zbawienie - według nich, wyznawców protestantyzmu - jest aktem łaski, nie wynika zaś $z$ zasług nagromadzonych w ciągu lat życia. Stąd marginesowe traktowanie laudacji. Pierre Chaunu zauważył, że w wieku XVIII „śmierć nie ma prawa obywatelstwa w mieście: jest sprawą prywatną, zostaje odsunięta ze swoją całą niewygodną treścią w krąg życia wewnętrznego i rodzinnego"70. Zamyka się $w$ domu, w gronie najbliższych. Kształtuje się tak nowy model przeżywania śmierci; rezygnuje się z barokowego gestu, ruchu, z barokowej teatralizacji śmierci.

Powiązanie poezji żałobnej z życiem rodzinnym najpełniej ujawniło się $w$ consolatio, w części obok komploracji szczególnie ważnej. Zamykała się ona niekiedy w kilku zaledwie wersach, nawet $w$ dwuwersie. Tak jak w epicedium synów Unselta:

Jedoch was dürfen wir jetzt unsern Gram vermehren? Gnug daß die Mutter lebt und Gott an Vaters statt.

${ }^{70}$ P. Chaunu, op. cit., s. 129. 
Tak również u cytowanego tu już Jana Unselta:

Jedoch des Himmels Schluß muß allzeit heilig heissen, Und was der Höchste thut, ist alles Wohl gemacht.

Mußt Du gleich früh von uns ins Land der Todten reisen

So wirst Du ja auch früh zum höchsten Glück gebracht.

Dodajmy, że towarzyszy tym słowom charakterystyczny motyw konsolacyjny: myśl o własnej śmierci, wyrażona zresztą równie zwięźle:

Kommt meine Zeit herbey und meine letzten Stunden, So für des Höchsten Hand auch mich Dir frölich zu!

Epicedium, podpisane przez dwóch przyjaciół - S. G. ${ }^{71}$ - złożone z dziewięciu 8-wersowych zwrotek, tworzących wypowiedź po części laudacyjną, po części komploracyjną, kończy się konsolacyjną pointą obejmującą zdanie pytajne, skierowane do wdowca po zmarłej właśnie Zuzannie Marii Weißschnur, i odpowiedź:

Wie kannst Du Deinen Schmerz ermüden?

Durch Gott, Vernuft, Geduld und Zeit.

Na ogół jednak były konsolacje znacznie obszerniejsze. Nie znany autor, podpisujący się literą „R.”, wystąpił po śmierci rajcy Gotfryda Meyera z wierszem jeśli nie w całości, to w znacznej mierze konsolacyjnym, przy czym słowa pocieszenia skierował do Gdańska, któremu zmarły służył, do wdowy po nim, matki i dzieci. Godne uwagi są tu argumenty konsolacyjne. Wybierzmy dwa charakterystyczne. Jeden pochodzi z części adresowanej do żony:

Dein Gatte prangt anjetzt in jenen Sternen-Bau, Ja woltest Du Ihn wohl dies seelge Glück mißgönnen?

drugi - do matki:

Laß fromme Mutter sich Dein bitter Schmerz verziehen, Laß so wohl Gram, als Leyd, aus Deiner Seele fliehen, Zwar wird auf Erden nicht Dir der Verlust ersetzt, Ja der Verlust, der itzt Dein dunkles Aug benetzt, Du wirst den theuren Sohn, den Du hier must vermissen, Dort in der Ewigkeit mit grössrer Freude küssen.

Perspektywa zbawienia należy bodaj do najczęstszych argumentów konsolacyjnych. Ukrywający się pod inicjałami J.G.B. autor w epicedium poświęconym

\footnotetext{
${ }^{71}$ Por. przyp. 61.
} 
pamięci Florentyny Karoliny Soermann ${ }^{72}$, pochodzącym z połowy XVIII wieku, zawarł taką oto myśl:

So kummervoll die Todes-Blicke

Die nicht Natur und Witz besiegt;

So groß ist auch des Christen Glücke,

Wenn er an Jesus Kreuze liegt;

Er reist sich loß von eiteln Sachen,

Und scheuet keine Sterbenbahn,

Wo Schlag und Fall inn glücklich machen

Und zu dem Himmel führen kan.

Do argumentów konsolacyjnych należała także myśl o tym, że śmierć kładzie kres cierpieniom i dopiero zmarli doznają prawdziwego szczęścia. Pojawia się ona między innymi w epicedium (autora znanego tylko od strony literonimu ${ }^{73}$ ) powstałym po zgonie Sary Florentyny Buchan, córki diakona w kościele Św. Piotra i Pawła. Czytamy tu:

Denn nur als wahre Himmels-Erben

Kann man dies Glück erst recht verstehn,

Da, wo sich aller Jammer endet,

Den man hier in der Welt gespührt...

W niebie żyje zmarły z dala od lęku i nędzy, a do najbliższych zdaje się zwracać ze słowami pocieszenia. To kolejny - istotny - składnik konsolacji:

Nun Freunde, die Ihr Sie beklaget, Erwegt das Glück, das Sie umgiebt; Ich höre, wie Sie zu Euch saget, Mein Vater, Freund, die Ihr mich liebt; Vergiesset nicht so bittre Thränen, Beweinet gar nicht meinen Tod, Laßt vielmehr wahre Freude thönen; Ich bin ja höchst beglückt bey Gott.

Jako argument konsolacyjny występuje również Chrystusowa obietnica zmartwychwstania:

Und wenn denn Christus wird erscheinen, Und Todte aus den Gräbeen gehn, Wird unter seinen Liebsten Kleinen, Auch ihm zur Seite Diese stehn.

72 J. G. B., Bey dem [...] Absterben der weyland [...] Frauen Florentina"Charlotta Soermannen, geborne Brayne, des [...] Herrn Johann Heinrich Soermann, Hochansehnlichen Schöppenherrn der Alten-Stadt Danzig, höchst beliebt gewesenen Gemahlin, welche den 5 Februanii 1756 bey ansehnlicher Leichen-Versammlung zur Erde bestattet wurde, wolte sein herliches Beyleid dem Hohen Soermannischen Hause hiedurch an den Tag legen, [Danzig 1756]. Egz. BG PAN, sygn. Oe $104522^{\circ}$.

${ }^{73}$ Por. przyp. 57. 
Towarzyszy temu często motyw spotkania ze zmarłym. Jest on obecny na przykład w zakończeniu ody żałobnej napisanej przez nie znanego autora, który przedstawił się jako Ergebenster ${ }^{74}$, po śmierci syna gdańskiego kupca Abrahama Clemensa:

\section{Faßt Euch, er steht in jenen Höhen Vor seines Heilands heilgem Thron, Wo ihr den Bruder und den Sohn Verklährt einst werdet wieder sehen.}

Najczęściej jednak śmierć przedstawiana bywa i jako kres trudnych chwil, uwolnienie od zmartwień i trosk, i jako początek nowego życia, życia wiecznego. Tak ją widział Beniamin Benedykt Henrichsdorff w epicedium napisanym po śmierci Eleonory Konstancji Löbe ${ }^{75}$ :

Nun endlich kommt der Tod, der Jederman gewiB

Und unvermeidlich ist. Dann wird man neu gebohren

Zu einem neuen Stand, aus dieser Finsterniß.

Das Leben dieser Erd wird zwar durch ihn verlohren:

Doch eine neue Welt eröfnet sich dem Blick.

Śmierć uszczęśliwia, prowadzi bowiem do życia pełnego radości:

So ist es denn gewß: Der Tod nur macht beglückt; Er ist der einzge Weg zum Freuden-vollen Leben...

I dalej:

Wer so, wie Jesus, stribt, frey, muthig, Gott vertraut, Der seegnet seinen Tod und wird in seinem Sterben Die frohe Ewigkeit, des Lebens Krone erben, In Hütten, die ihm sebst sein Heyland aufgebaut.

Konsolacje przenika silna wiara w Chrystusa, w działania jego przykładu, przekonanie, że człowiek, który zaufał Bogu - jak Chrystus - może być pewny zbawienia. Dochodzi ona do głosu także w kazaniach pogrzebowych, do których epicedia często dodawano. Wspomniany już Richter kazanie na pogrzebie Zerneckego oparł na słowach psalmu 90 (91): Herr Gott du bist unser Zuflucht für und für. Według kaznodziei umierający miał swoją ostatnią spowiedź zacząć od słów: Zu dir mein Gott flieh ich, verstoß mich nicht, wie ichs wol hab verdienet, ach Gott zürne nicht, geh nicht ins Gericht, dein Sohn hat mich versühnet... ${ }^{76}$. Tenże Ri-

${ }^{74}$ Por. przyp. 58.

${ }^{75}$ Por. przyp. 63.

${ }^{75} \mathrm{G}$. Richter, Gott, als der Gläubigen beständige Zuflucht in der Noth, hat, als der weyland [...] Herr Jacob Heinrich Zernecke [...] im wahren Glauben seelig entschlaffen..., op. cit., s. 8. 
chter w kazaniu na pogrzebie Unselta powiedział: Zwar haben wir nur ein eintziges vollkommenes und gantz untadelhaftes Fürbild; das ist Jesus unser Heyland, von welchem Petrus schreibet I Ep. II, 22 Christus hat uns ein Fürbild gelassen, daß ihr sollt nachfolgen seinen Fußstapfen ${ }^{77}$.

W konsolacji nie usiłuje się - w imię doraźnych celów - wtargnąc w sposób brutalny w życie, rozprawiać się z jego różnymi aspektami, by w ten sposób pocieszyć najbliższych zmarłego. Obce są jej myśli o odrzuceniu wzorców typu homo artifex, homo politicus, homo ludens, z czym można się było spotkać w XVI czy $\mathrm{XVII}$ wieku ${ }^{78}$. Niewiele tu o trudach i niebezpieczeństwach życia, jego niepewności i tymczasowości; nie tworzy się opozycji między doczesnym życiem a wizją szczęścia po śmierci. Nie znajdziemy też rozważań wanitatywnych; nieczęsto odzywają się barokowe obsesje temporaine.

Uderza kameralność argumentacji. Przy jej udziale budują konsolację członkowie rodziny, z nią się zwracają do tych, którzy utracili swych najbliższych. Przedstawiają śmierć jako kres cierpienia, głoszą przekonanie o jej nieuchronności, lecz akceptacja, na jaką się zdobywają, nie prowadzi do pragnienia śmierci. Zmierzają do jej antropomorfizacji, do uczłowieczenia przez racjonalizację. Szukają argumentów dla jej zrozumienia i w ten sposób usiłują rozproszyć grozę śmierci. Temu celowi służy też eksponowana przez autorów perspektywa zbawienia. Trzeba także zauważyć, że śmierć nie pojawia się u nich jako siła stanowiąca zaprzeczenie wielkości i godności człowieka, choć oczywiście świadomość tego, że powoduje ona zerwanie więzi rodzinnych, przyjacielskich, jest w epicediach bardzo wyraźna.

Na gdańską poezję rodzinną złożyły się - o czym mogliśmy się przekonać przede wszystkim genetliakony i wiersze pisane na dies natalis, epitalamia oraz wiersze funeralne, wyrastające z europejskiego dziedzictwa literackiego, często jednak realizujące indywidualne pomysły autorów. W kręgu rodzinnym powstawały również utwory z okazji na przykład wyniesienia na urząd czy propemptikony, w których żegnano synów, braci i przyjaciół wyruszających na studia. Nie czas tu jednak i miejsce, by je omawiać. Jedno jest pewne: w mieście nad Motławą utrwalił się w ciągu XVIII wieku zwyczaj wzbogacania życia domowego słowem poetyckim, wykorzystywanym przy rozmaitych okazjach. Naśladowano w ten sposób rytuały, które wcześniej ukształtowały się w życiu publicznym, w strukturze szkolnictwa, a Gdańskiego Gimnazjum Akademickiego w szczególności. Wszak pisano epitalamia na cześć rajców, burmistrzów, profesorów, gdy zawierali związki małżeńskie, genetliakony, gdy ich potomkowie przychodzili na świat lub gdy oni sami obchodzili rocznice swych urodzin, epitafia i epicedia, gdy oni sami lub członkowie ich rodzin umierali. Bohaterami i adresatami analogicznych utworów bywali także królowie, dostojnicy państwa. W ten sposób tworzył się w Gdańsku jednocześnie i obyczaj, i model literacki, który z czasem stał się przedmiotem naślado-

\footnotetext{
${ }^{77}$ G. Richter, Als ein Fürbild der Gläubigen [...] ward der weyland [...] Herr Johann Daniel Unselt..., op. cit., s. 3

${ }^{78}$ Por.: A. Nowicka-Jeżowa, Pieśń czasu śmierci. Studium z historii duchowości XVI-XVIII wieku. Lublin 1992, s. 87.
} 
wania ze strony patrycjuszy, mieszczan. Miasto dostarczyło wzorów rodzinie, a rodzina z kolei miastu, bo miasto było - jak pisał przed wiekami humanista włoski, Leon Battista Alberti - ,jednym wielkim domem, a dom przeciwnie jakby małym miastem"79.

${ }^{79}$ L. B. Alberti, Ksiąg dziesięć o sztuce budowania. Tłum. I. Biegańska. Warszawa 1960, s. 33 